\title{
LEVEL II SCOUR ANALYSIS FOR BRIDGE 26 (WSTOTH00070026) on TOWN HIGHWAY 7, crossing GREENDALE BROOK, WESTON, VERMONT
}

U.S. Geological Survey Open-File Report 97-576

Prepared in cooperation with

VERMONT AGENCY OF TRANSPORTATION and

FEDERAL HIGHWAY ADMINISTRATION 


\section{LEVEL II SCOUR ANALYSIS FOR BRIDGE 26 (WSTOTH00070026) on TOWN HIGHWAY 7, crossing GREENDALE BROOK, WESTON, VERMONT \\ By Lora K. Striker and Robert A. Hammond}

U.S. Geological Survey Open-File Report 97-576

Prepared in cooperation with

VERMONT AGENCY OF TRANSPORTATION

and

FEDERAL HIGHWAY ADMINISTRATION 


\title{
U.S. DEPARTMENT OF THE INTERIOR BRUCE BABBITT, Secretary
}

\author{
U.S. GEOLOGICAL SURVEY \\ Gordon P. Eaton, Director
}

For additional information write to:

District Chief

U.S. Geological Survey 361 Commerce Way

Pembroke, NH 03275-3718
Copies of this report may be purchased from:

U.S. Geological Survey

Branch of Information Services

Open-File Reports Unit

Box 25286

Denver, CO 80225-0286 


\section{CONTENTS}

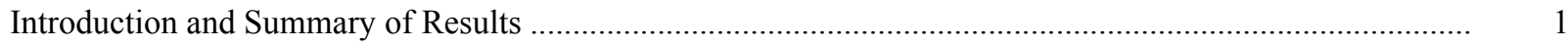

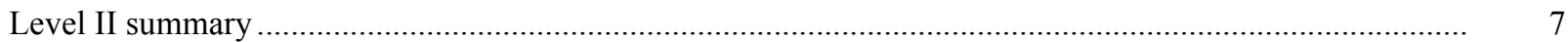

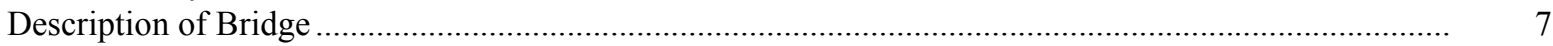

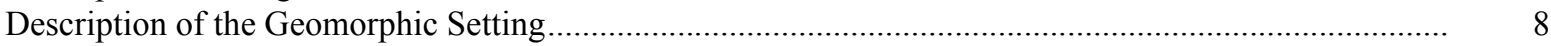

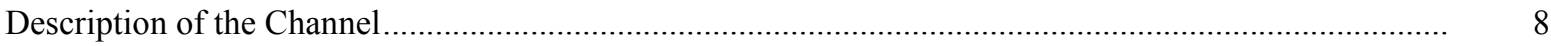

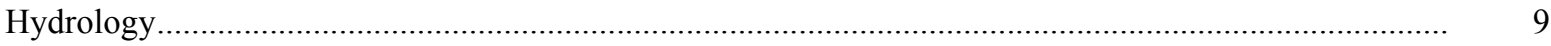

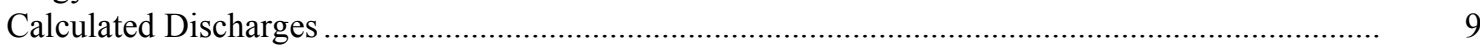

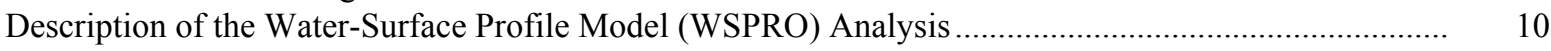

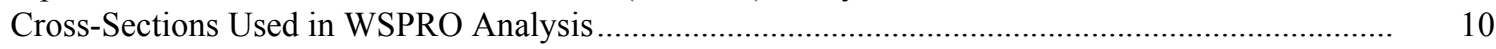

Data and Assumptions Used in WSPRO Model ...................................................................... 11

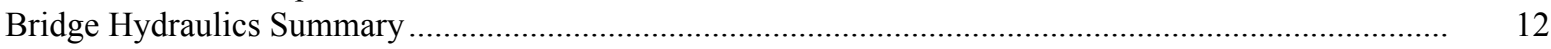

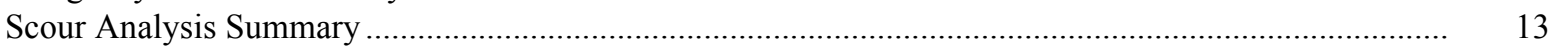

Special Conditions or Assumptions Made in Scour Analysis ...................................................... 13

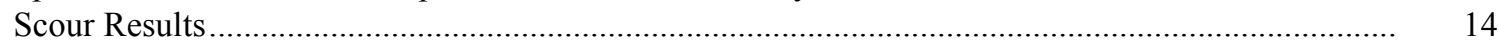

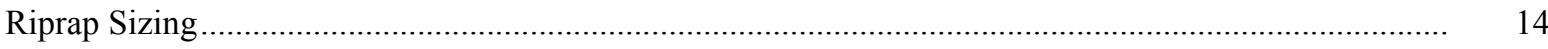

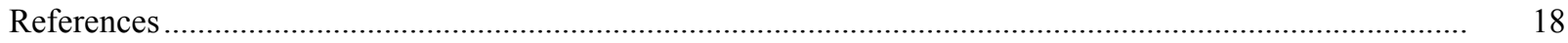

Appendixes:

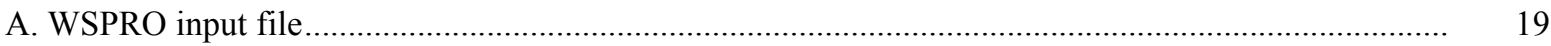

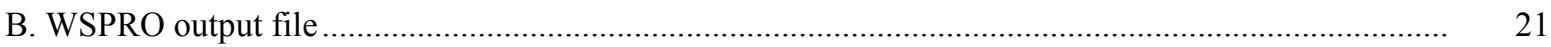

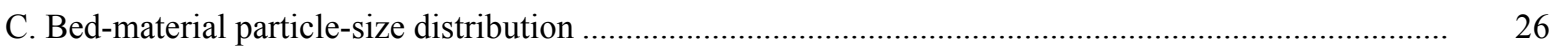

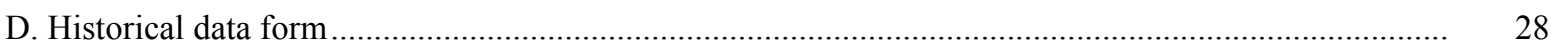

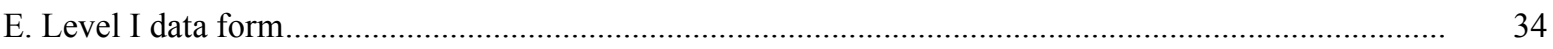

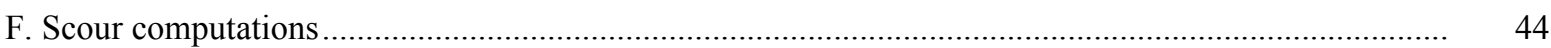

\section{FIGURES}

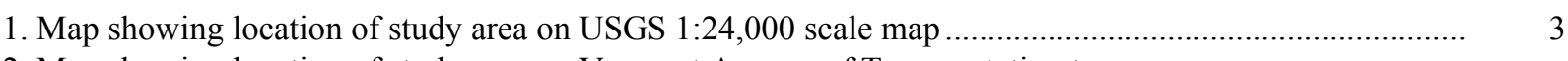

2. Map showing location of study area on Vermont Agency of Transportation town
highway map

3. Structure WSTOTH00070026 viewed from upstream (August 19, 1996) .............................................. 5

4. Downstream channel viewed from structure WSTOTH00070026 (August 19, 1996)............................ 5

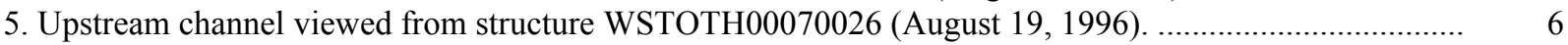

6. Structure WSTOTH00070026 viewed from downstream (August 19, 1996)....................................... 6

7. Water-surface profiles for the 100- and 500-year discharges at structure WSTOTH00070026 on Town Highway 7, crossing Greendale Brook,

Weston, Vermont..

8. Scour elevations for the 100- and 500-year discharges at structure

WSTOTH00070026 on Town Highway 7, crossing Greendale Brook,

Weston, Vermont.

\section{TABLES}

1. Remaining footing/pile depth at abutments for the 100-year discharge at structure

WSTOTH00070026 on Town Highway 7, crossing Greendale Brook,

Weston, Vermont

2. Remaining footing/pile depth at abutments for the 500-year discharge at structure

WSTOTH00070026 on Town Highway 7, crossing Greendale Brook,

Weston, Vermont 


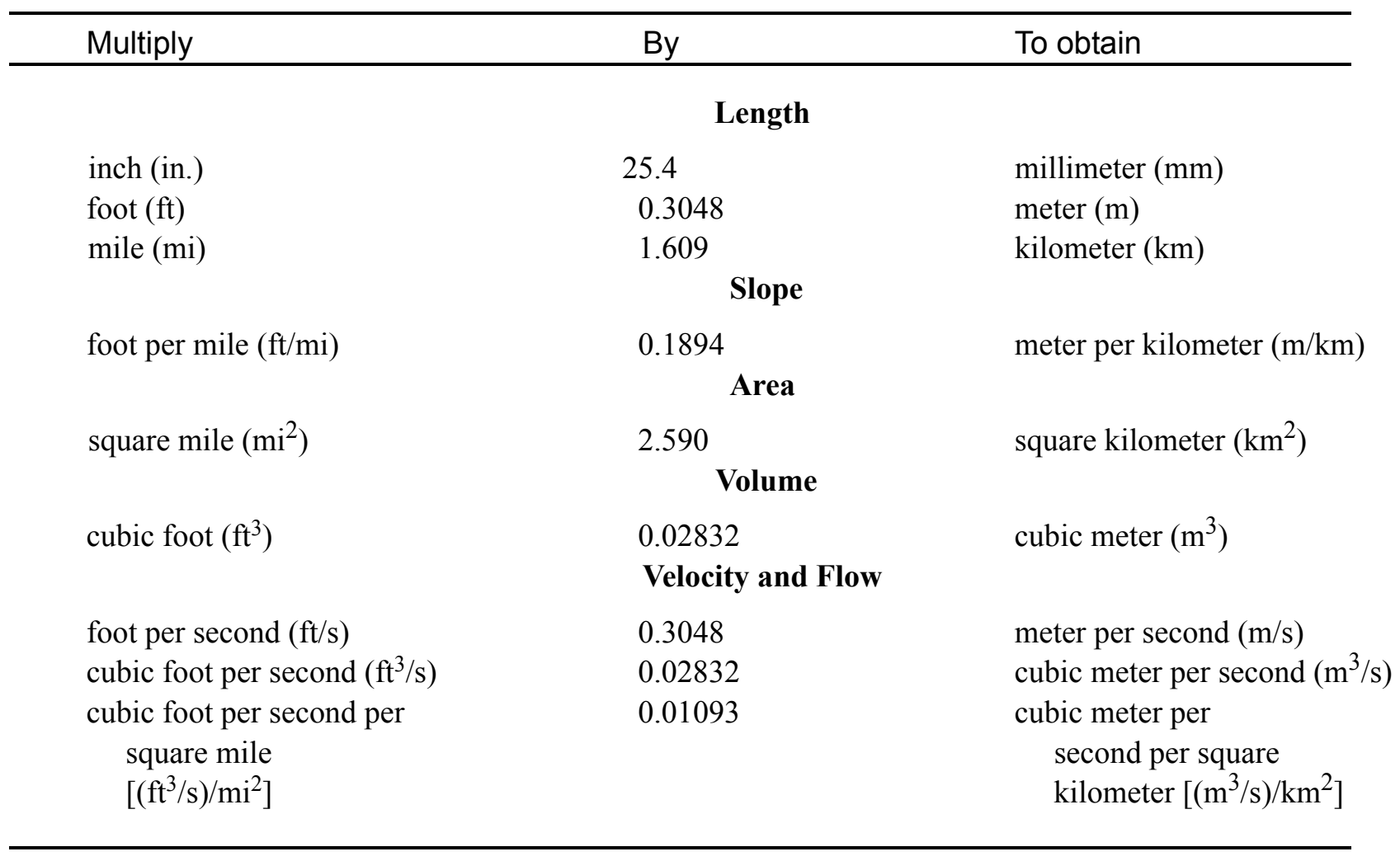

\section{OTHER ABBREVIATIONS}

$\begin{array}{lrlr}\mathrm{BF} & \text { bank full } & \text { LWW } & \text { left wingwall } \\ \mathrm{cfs} & \text { cubic feet per second } & \text { MC } & \text { main channel } \\ \mathrm{D}_{50} & \text { median diameter of bed material } & \text { RAB } & \text { right abutment } \\ \mathrm{DS} & \text { downstream } & \text { RABUT } & \text { face of right abutment } \\ \mathrm{elev} & \text { elevation } & \text { RB } & \text { right bank } \\ \mathrm{f} / \mathrm{p} & \text { flood plain } & \text { ROB } & \text { right overbank } \\ \mathrm{ft}^{2} & \text { square feet } & \text { RWW } & \text { right wingwall } \\ \mathrm{ft} / \mathrm{ft} & \text { feet per foot } & \text { TH } & \text { town highway } \\ \mathrm{JCT} & \text { junction } & \text { UB } & \text { under bridge } \\ \mathrm{LAB} & \text { left abutment } & \text { US } & \text { upstream } \\ \mathrm{LABUT} & \text { face of left abutment } & \text { USGS } & \text { United States Geological Survey } \\ \mathrm{LB} & \text { left bank } & \text { VTAOT Vermont Agency of Transportation } \\ \mathrm{LOB} & \text { left overbank } & \text { WSPRO } & \text { water-surface profile model }\end{array}$

In this report, the words "right" and "left" refer to directions that would be reported by an observer facing downstream. Sea level: In this report, "sea level" refers to the National Geodetic Vertical Datum of 1929-- a geodetic datum derived from a general adjustment of the first-order level nets of the United States and Canada, formerly called Sea Level Datum of 1929.

In the appendices, the above abbreviations may be combined. For example, USLB would represent upstream left bank. 


\title{
LEVEL II SCOUR ANALYSIS FOR BRIDGE 26 (WSTOTH00070026) ON TOWN HIGHWAY 7, CROSSING GREENDALE BROOK, WESTON, VERMONT
}

\author{
By Lora K. Striker and Robert A. Hammond
}

\section{INTRODUCTION AND SUMMARY OF RESULTS}

This report provides the results of a detailed Level II analysis of scour potential at structure WSTOTH00070026 on Town Highway 7 crossing Greendale Brook, Weston, Vermont (figures 1-8). A Level II study is a basic engineering analysis of the site, including a quantitative analysis of stream stability and scour (U.S. Department of Transportation, 1993). Results of a Level I scour investigation also are included in Appendix E of this report. A Level I investigation provides a qualitative geomorphic characterization of the study site. Information on the bridge, gleaned from Vermont Agency of Transportation (VTAOT) files, was compiled prior to conducting Level I and Level II analyses and is found in Appendix D.

The site is in the Green Mountain section of the New England physiographic province in south central Vermont. The $3.13-\mathrm{mi}^{2}$ drainage area is in a predominantly rural and forested basin. In the vicinity of the study site, the surface cover is forest.

In the study area, the Greendale Brook has a sinuous, non-incised, non-alluvial channel with a slope of approximately $0.015 \mathrm{ft} / \mathrm{ft}$, an average channel top width of $38 \mathrm{ft}$ and an average bank height of $3 \mathrm{ft}$. The channel bed material ranges from sand to boulder with a median grain size $\left(\mathrm{D}_{50}\right)$ of $64.8 \mathrm{~mm}(0.213 \mathrm{ft})$. The geomorphic assessment at the time of the Level I and Level II site visit on August 19, 1996, indicated that the reach was laterally unstable. The channel has moved to the right, however, scour countermeasures are in place along the upstream right bank.

The Town Highway 7 crossing of the Greendale Brook is a 52-ft-long, two-lane bridge consisting of one 50-foot steel-beam span with a concrete deck (Vermont Agency of Transportation, written communication, April 07, 1995). The opening length of the structure parallel to the bridge face is $48.6 \mathrm{ft}$. The bridge is supported by vertical, concrete abutments with wingwalls. The channel is skewed approximately 50 degrees to the opening while the opening-skew-to-roadway is 30 degrees. 
A scour hole $1.5 \mathrm{ft}$ deeper than the mean thalweg depth was observed along the upstream right wingwall and right abutment during the Level I assessment. Scour protection measures at the site include: type- 2 stone fill (less than 36 inches diameter) at the upstream end of the upstream left wingwall, along the left bank upstream, at the downstream end of the downstream left wing wall, and along the entire length of the downstream right wing wall; type 4 (less than 60 inches) and type- 3 stone fill (less than 48 inches) along the right bank upstream. Additional details describing conditions at the site are included in the Level II Summary and Appendices D and E.

Scour depths and recommended rock rip-rap sizes were computed using the general guidelines described in Hydraulic Engineering Circular 18 (Richardson and others, 1995). Total scour at a highway crossing is comprised of three components: 1) long-term streambed degradation; 2) contraction scour (due to accelerated flow caused by a reduction in flow area at a bridge) and; 3 ) local scour (caused by accelerated flow around piers and abutments). Total scour is the sum of the three components. Equations are available to compute depths for contraction and local scour and a summary of the results of these computations follows.

Contraction scour for all modelled flows was $0.0 \mathrm{ft}$. Abutment scour ranged from 3.9 to 9.9 $\mathrm{ft}$. The worst-case abutment scour occurred at the 500-year discharge. Additional information on scour depths and depths to armoring are included in the section titled "Scour Results". Scoured-streambed elevations, based on the calculated scour depths, are presented in tables 1 and 2. A cross-section of the scour computed at the bridge is presented in figure 8. Scour depths were calculated assuming an infinite depth of erosive material and a homogeneous particle-size distribution.

It is generally accepted that the Froehlich equation (abutment scour) gives "excessively conservative estimates of scour depths" (Richardson and others, 1995, p. 47). The Hire equation (abutment scour) is often used when the horizontal length blocked by flow divided by the depth of flow is greater than 25 (Richardson and others, 1995 p. 49). Although the Hire equation could be applied to the left abutment more conservative scour estimates were given by the Froehlich equation on the left abutment. Usually, computed scour depths are evaluated in combination with other information including (but not limited to) historical performance during flood events, the geomorphic stability assessment, existing scour protection measures, and the results of the hydraulic analyses. Therefore, scour depths adopted by VTAOT may differ from the computed values documented herein. 


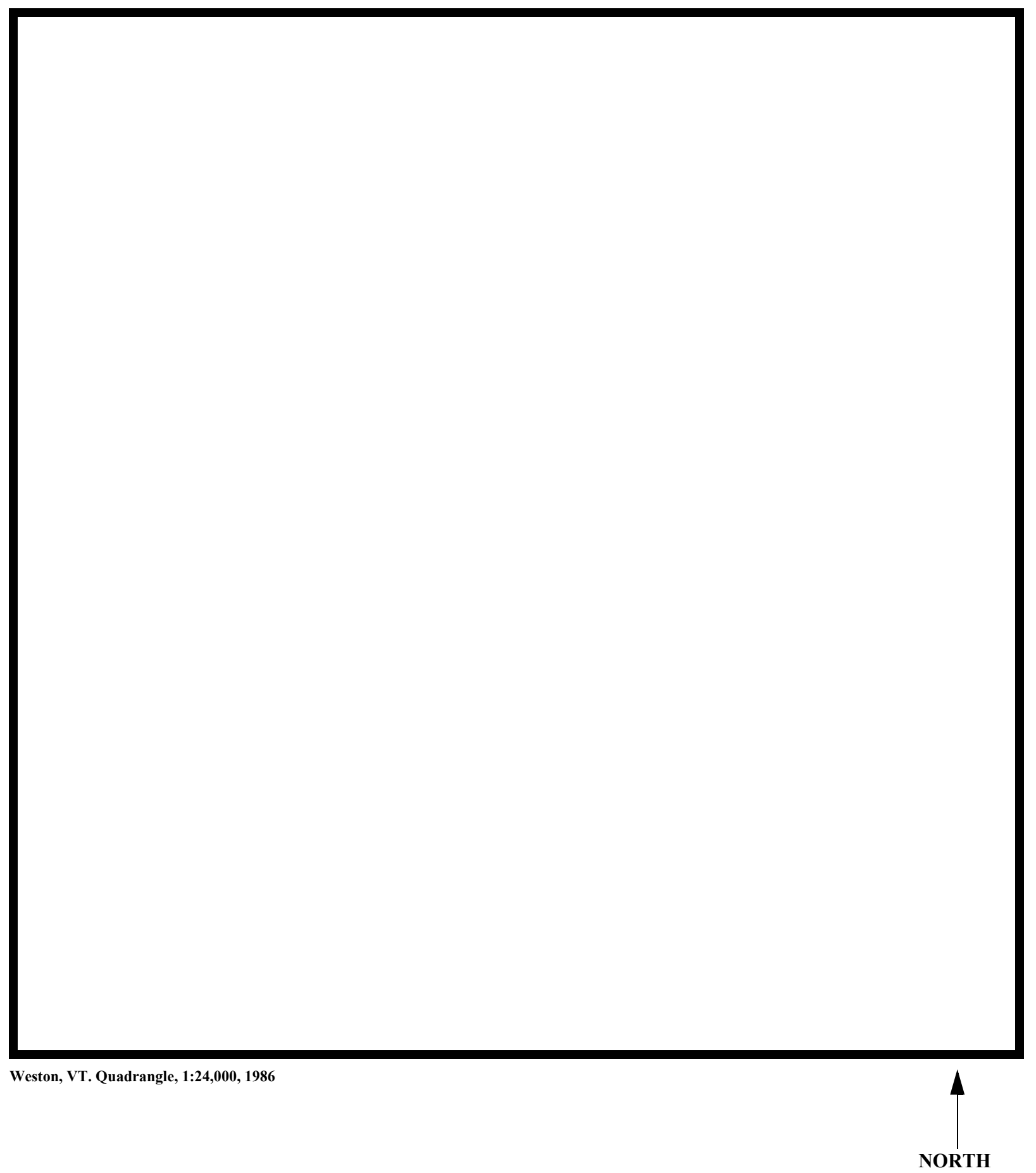

Figure 1. Location of study area on USGS 1:24,000 scale map. 
Figure 2. Location of study area on Vermont Agency of Transportation town highway map. 

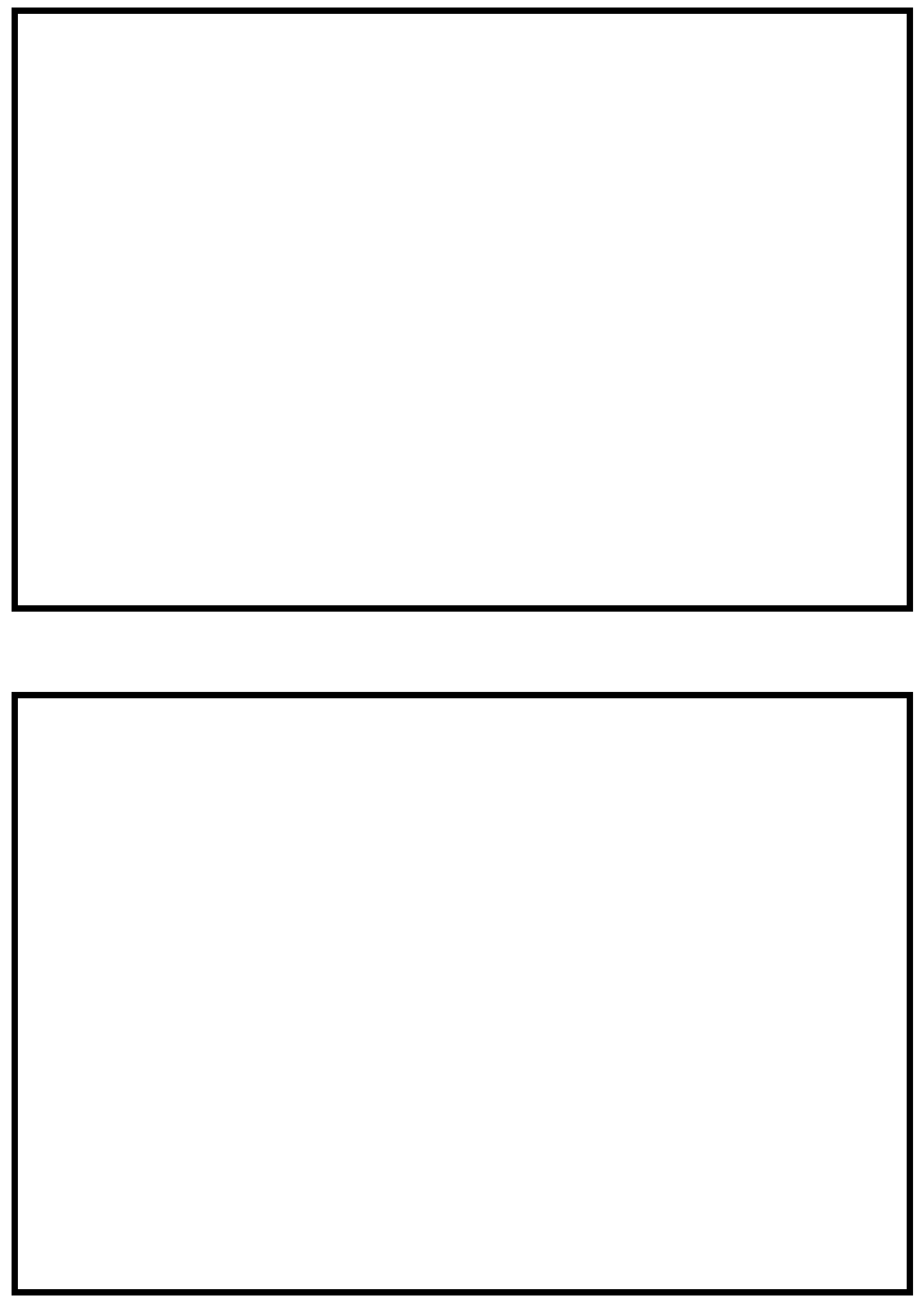

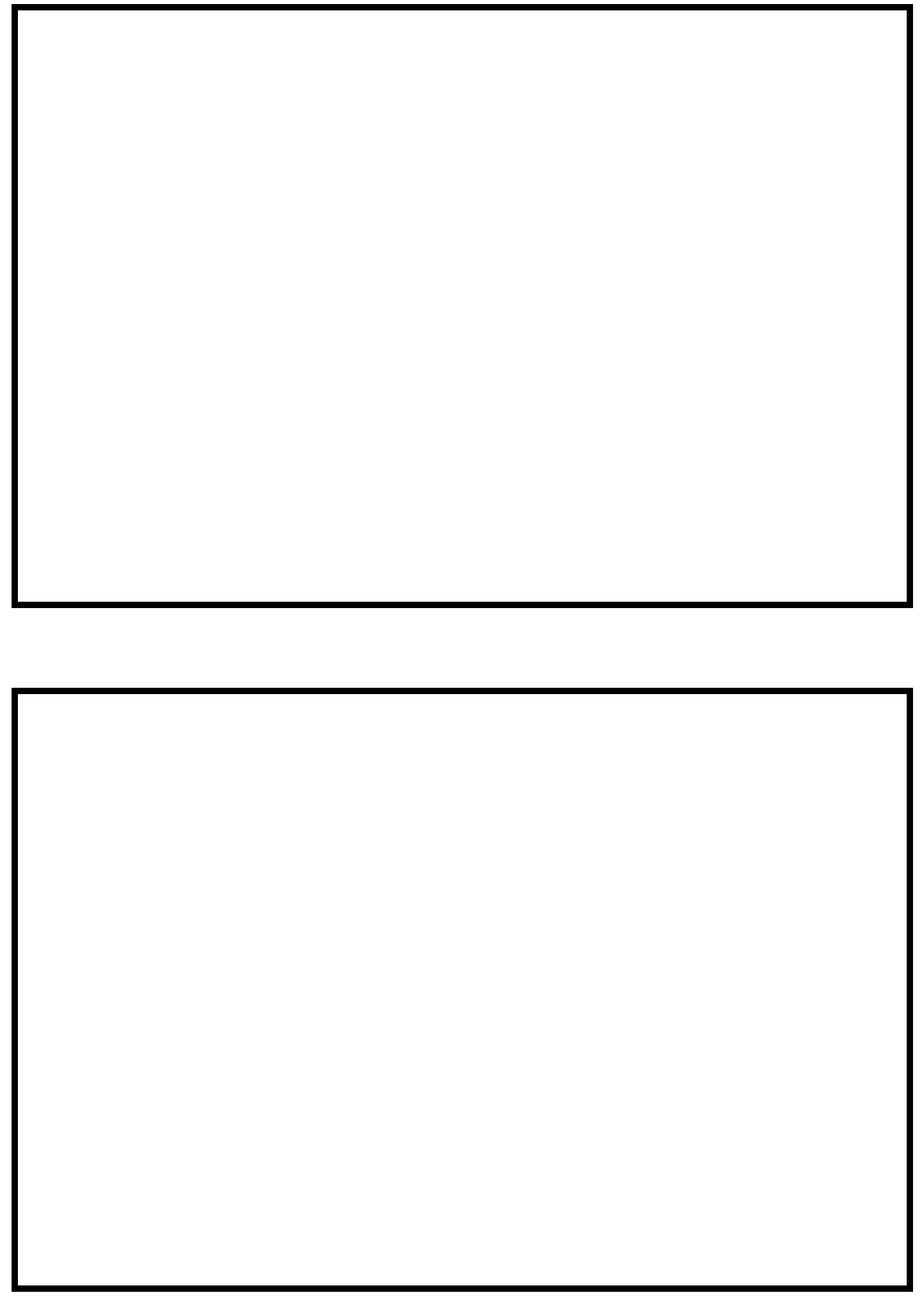


\section{LEVEL II SUMMARY}

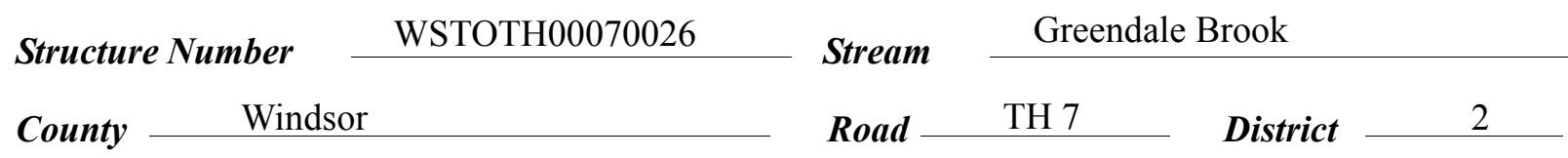

\section{Description of Bridge}

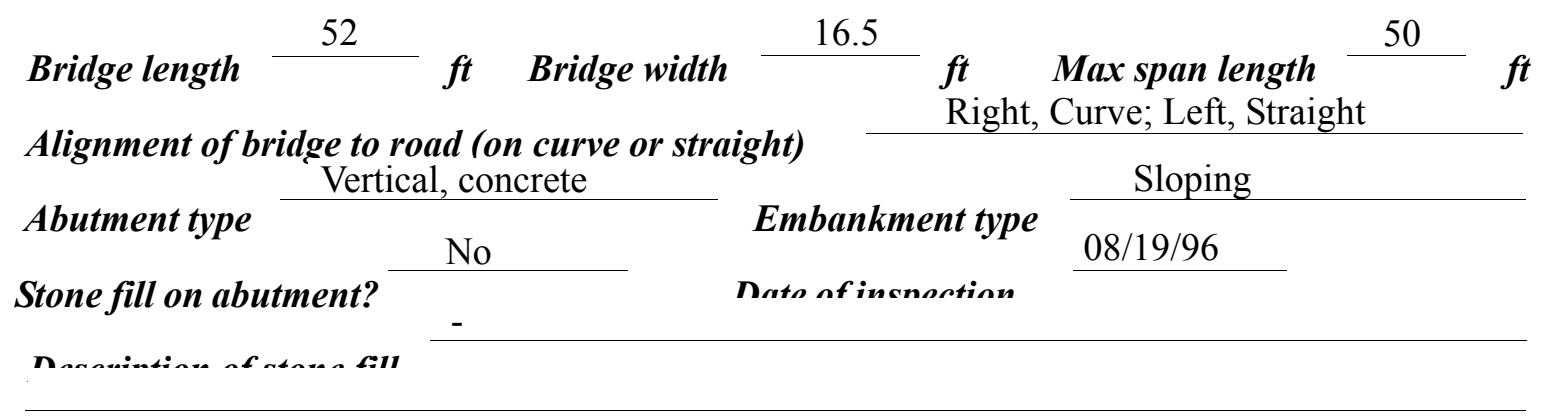

Abutments and wingwalls are concrete. There is a one

to two foot deep scour hole at the upstream right wingwall and along the right abutment.

$$
\text { Y }
$$

$\underline{50} \quad \underline{\mathrm{Y}}$

Is bridge skewed to flood flow according to Sever ' survey? Angle

e. There is sediment build up along the left abutment at the bridge blocking $50 \%$ of the channel opening at low flows.

Debris accumulation on bridge at time of Level I or Level II site visit:

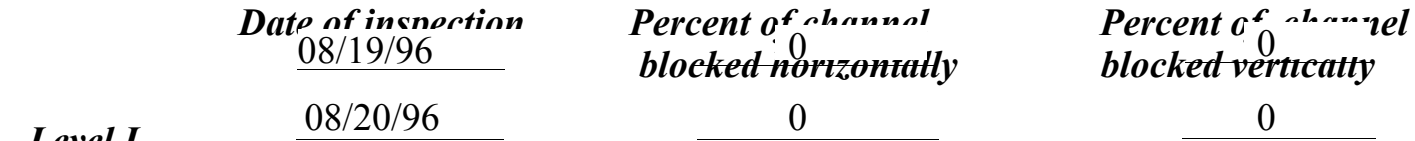

Level I

Moderate. Base of trees and exposed roots along both banks show

Level II

debris impacts.

Pcars from ice and/or

There is a pointbar that is vegetated along the left bank at the bridge opening that forces flow Doscriho any foaturos noar ar at tho hridoo that mav affort flow, (includo ahsorvation dato) along the right abutment during low flows. 


\section{Description of the Geomorphic Setting}

General topography The channel is located in a moderate relief valley, with little or no flood plains and concave natural levees.

Geomorphic conditions at bridge site: downstream (DS), upstream (US)

Date of inspection $\quad 08 / 19 / 96$

DS left: $\quad$ Moderately sloped overbank

DS right: $\quad$ Moderately sloped overbank

US left: $\quad$ Moderately sloped channel bank to narrow flood plain.

US right: $\quad$ Moderately sloped overbank

\section{Description of the Channel}

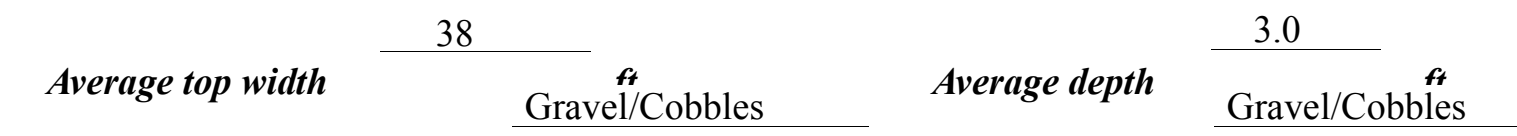

Predominant bed material Bank material Sinuous and laterally

unstable with non-alluvial channel boundaries and little to no flood plains.

Vegetative co 1 Trees

DS left: $\quad$ Trees

DS right: Trees

US left: $\quad$ Trees.

US right:

$\mathrm{N}$

Do banks appear stable? The left and right banks are cut from the bridge to 250 feet unstream. The channel is migrating to the right at the bridge. There is a cut-bank along the right bank
date of observattont. inside bend from 35 to 85 feet downstream.

Describe any obstructions in channel and date of observation. 


\title{
Hydrology
}

Drainage area $\quad 3.13 \mathrm{mi}^{2}$

Percentage of drainage area in physiographic provinces: (approximate)

Physiographic province/section

New England/Green Mountain
Percent of drainage area 100

\begin{abstract}
Is drainage area considered rural or urban? Rural Describe any significant urbanization:
\end{abstract}

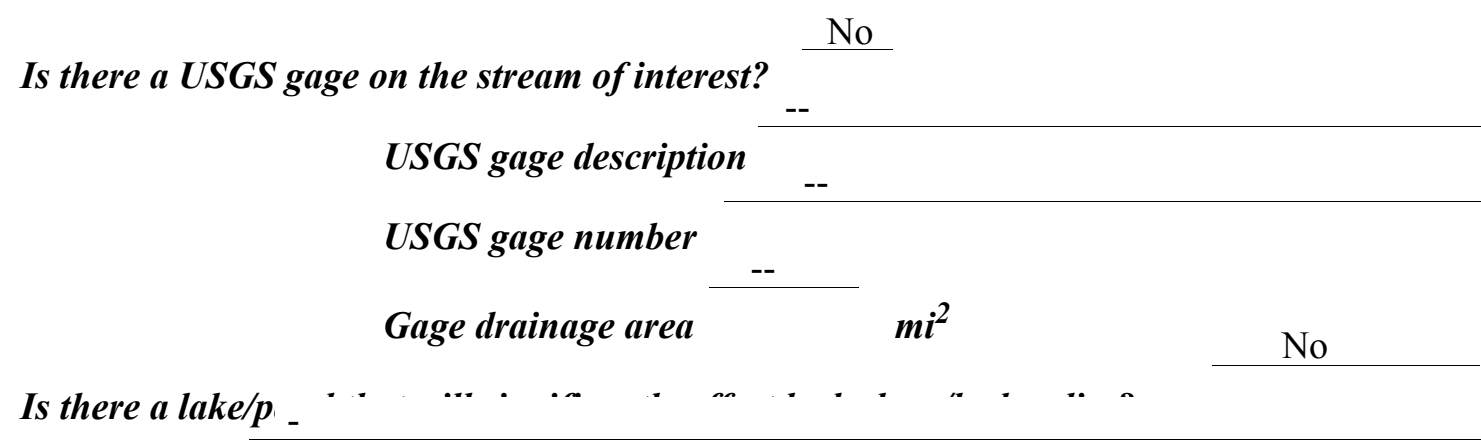

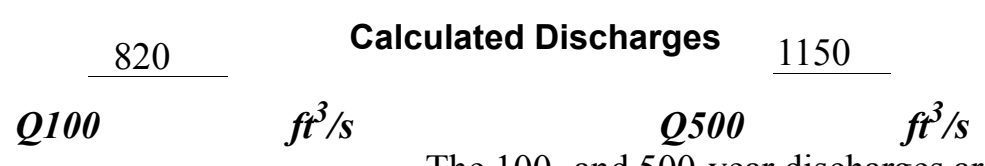

The 100- and 500-year discharges are based on the

median values of flood frequency curves determined from empirical relationships for Greendale Brook. (Benson, 1962; Johnson and Tasker, 1974; FHWA, 1983; Potter, 1957a\&b; Talbot, 1887) 


\section{Description of the Water-Surface Profile Model (WSPRO) Analysis}

Datum for WSPRO analysis (USGS survey, sea level, VTAOT plans)

USGS survey

Datum tie between USGS survey and VTAOT plans

None

Description of reference marks used to determine USGS datum. $\quad$ RM1 is a chiseled X on top of the downstream end of the left abutment (elev. $500.41 \mathrm{ft}$, arbitrary survey datum). RM2 is

a chiseled $\mathrm{X}$ on top of the upstream end of the right abutment

(elev. $500.44 \mathrm{ft}$, arbitrary survey datum).

\section{Cross-Sections Used in WSPRO Analysis}

\begin{tabular}{cccl}
\hline${ }^{1}$ Cross-section & $\begin{array}{c}\text { Section } \\
\text { Reference } \\
\text { Distance } \\
\text { (SRD) } \text { in feet }\end{array}$ & $\begin{array}{c}{ }^{2} \text { Cross-section } \\
\text { development }\end{array}$ & \multicolumn{1}{c}{ Comments } \\
\hline EXITX & -52 & 1 & $\begin{array}{l}\text { Exit section } \\
\text { Downstream Full-valley } \\
\text { section (Templated from } \\
\text { EXITX) }\end{array}$ \\
FULLV & 0 & 2 & $\begin{array}{l}\text { Bridge section } \\
\text { Road Grade section }\end{array}$ \\
RDWHY & 0 & 1 & $\begin{array}{l}\text { Modelled Approach sec- } \\
\text { tion (Templated from } \\
\text { APTEM) }\end{array}$ \\
APTEM & 13 & 1 & $\begin{array}{l}\text { Approach section as sur- } \\
\text { veyed (Used as a tem- } \\
\text { plate) }\end{array}$ \\
\hline
\end{tabular}

${ }^{1}$ For location of cross-sections see plan-view sketch included with Level I field form, Appendix E. For more detail on how cross-sections were developed see WSPRO input file. 


\section{Data and Assumptions Used in WSPRO Model}

Hydraulic analyses of the reach were done by use of the Federal Highway Administration's WSPRO step-backwater computer program (Shearman and others, 1986, and Shearman, 1990). The analyses reported herein reflect conditions existing at the site at the time of the study. Furthermore, in the development of the model it was necessary to assume no accumulation of debris or ice at the site. Results of the hydraulic model are presented in the Bridge Hydraulic Summary, Appendix B, and figure 7.

Channel roughness factors (Manning's “ $n$ ”) used in the hydraulic model were estimated using field inspections at each cross section following the general guidelines described by Arcement and Schneider (1989). Final adjustments to the values were made during the modelling of the reach. Channel " $n$ " value for the reach was 0.065 , and overbank " $n$ " value was 0.075 .

Normal depth at the exit section (EXITX) was assumed as the starting water surface. This depth was computed by use of the slope-conveyance method outlined in the user's manual for WSPRO (Shearman, 1990). The slope used was $0.015 \mathrm{ft} / \mathrm{ft}$ which was estimated from the topographic map (U.S. Geological Survey, 1986).

The surveyed approach section (APTEM) was moved along the approach channel slope $(0.022 \mathrm{ft} / \mathrm{ft})$ to establish the modelled approach section (APPRO), one bridge length upstream of the upstream face as recommended by Shearman and others (1986). This location also provides a consistent method for determining scour variables. 


\section{Bridge Hydraulics Summary}

\begin{tabular}{llll} 
Average bridge embankment elevation & 500.4 \\
\cline { 3 - 3 } Average low steel elevation & 496.5 & $\boldsymbol{f t}$
\end{tabular}

100-year discharge $\quad 820 \quad \mathrm{ft}^{3} / \mathrm{s}$

Water-surface elevation in bridge opening $\quad 489.8 \quad f t$

Road overtopping? ___ N Discharge over road __ $\quad$\begin{tabular}{lll}
$\mathrm{ft}^{3} / \mathrm{s}$ \\
\hline
\end{tabular}

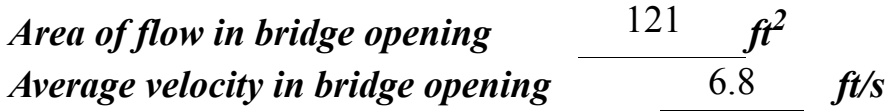

Maximum WSPRO tube velocity at bridge $\quad 9.8 \mathrm{ft} / \mathrm{s}$

Water-surface elevation at Approach section with bridge $\quad 492.0$

Water-surface elevation at Approach section without bridge $\quad \overline{490.4}$

Amount of backwater caused by bridge $\quad 1.6$ it

500-year discharge $\quad \begin{array}{ll}1150 & \mathrm{ft}^{3} / \mathrm{s}\end{array}$

Water-surface elevation in bridge opening $490.4 \mathrm{ft}$

Road overtopping? ___ N Discharge over road __ $\quad$\begin{tabular}{lll}
$\mathrm{ft}^{3} / \mathrm{s}$ \\
\hline
\end{tabular}

Area of flow in bridge opening $\quad 143 \quad \mathrm{ft}^{2}$

Average velocity in bridge opening $8.0 \mathrm{ft} / \mathrm{s}$

Maximum WSPRO tube velocity at bridge 11.4 ,

Water-surface elevation at Approach section with bridge 492.9

Water-surface elevation at Approach section without bridge $\quad 491.1$

Amount of backwater caused by bridge $1.8, t$

Incipient overtopping discharge ___ _ $\mathrm{ft}^{3} / \mathrm{s}$

Water-surface elevation in bridge opening $\quad-\quad t$

Area of flow in bridge opening _ _ _ $\mathrm{ft}^{2}$

Average velocity in bridge opening $\quad-\quad f t / s$

Maximum WSPRO tube velocity at bridge _ _ $\quad \mathrm{ft} / \mathrm{s}$

Water-surface elevation at Approach section with bridge

Water-surface elevation at Approach section without bridge

Amount of backwater caused by bridge _ _ _ it 


\section{Scour Analysis Summary}

\section{Special Conditions or Assumptions Made in Scour Analysis}

Scour depths were computed using the general guidelines described in Hydraulic Engineering Circular 18 (Richardson and others, 1995). Scour depths were calculated assuming an infinite depth of erosive material and a homogeneous particle-size distribution. The results of the scour analysis are presented in tables 1 and 2 and a graph of the scour depths is presented in figure 8 .

Contraction scour for the 100- and 500-year discharges were computed by use of the clear-water contraction scour equation (Richardson and others, 1995, p. 32, equation 20). At this site, the 100- and 500-year discharges resulted in free surface flow. Results of this analysis are presented in figure 8 and tables 1 and 2. The streambed armoring depths computed suggest that armoring will limit the depth of contraction scour.

Abutment scour was computed by use of the Froehlich equation (Richardson and others, 1995, p. 48, equation 28). Variables for the Froehlich equation include the Froude number of the flow approaching the embankments, the length of the embankment blocking flow, and the depth of flow approaching the embankment less any roadway overtopping.

Scour at the left abutment for the 100- and 500-year discharges was also computed by use of the HIRE equation (Richardson and others, 1995, p. 49, equation 29). The HIRE equation is recommended when the length to depth ratio of the embankment blocking flow exceeds 25 . The variables used by the HIRE abutment-scour equation are defined the same as those defined for the Froehlich abutment-scour equation. Although scour was calculated using the HIRE equation the scour results reported in figure 8 and tables 1 and 2 are from the Froehlich equation which gives a more conservative estimate for scour at this site. 


\section{Scour Results}

100-yr discharge 500-yr discharge

Incipient

Contraction scour:

(Scour depths in feet)

Main channel

$$
\begin{aligned}
& \text { Live-bed scour } \\
& \text { Clear-water scour } \\
& \text { Depth to armoring }
\end{aligned}
$$

Left overbank

Right overbank

Local scour:

Abutment scour

Left abutment

3.9
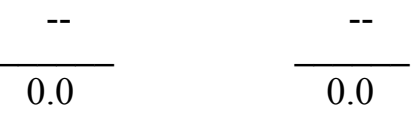

$1.7^{-}$

$4.2^{-}$

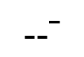

overtopping

discharge

Left abutment
Right abutment

Pier scour

Pier 1

Pier 2

Pier 3

Abutments:

Left abutment

Right abutment

Piers:

Pier 1

Pier 2

\section{Riprap Sizing}

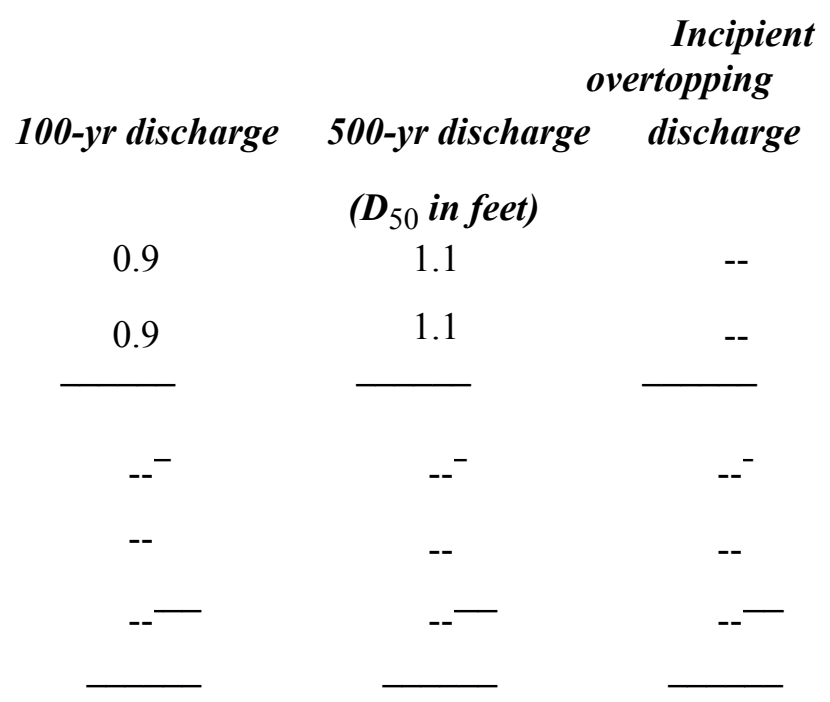




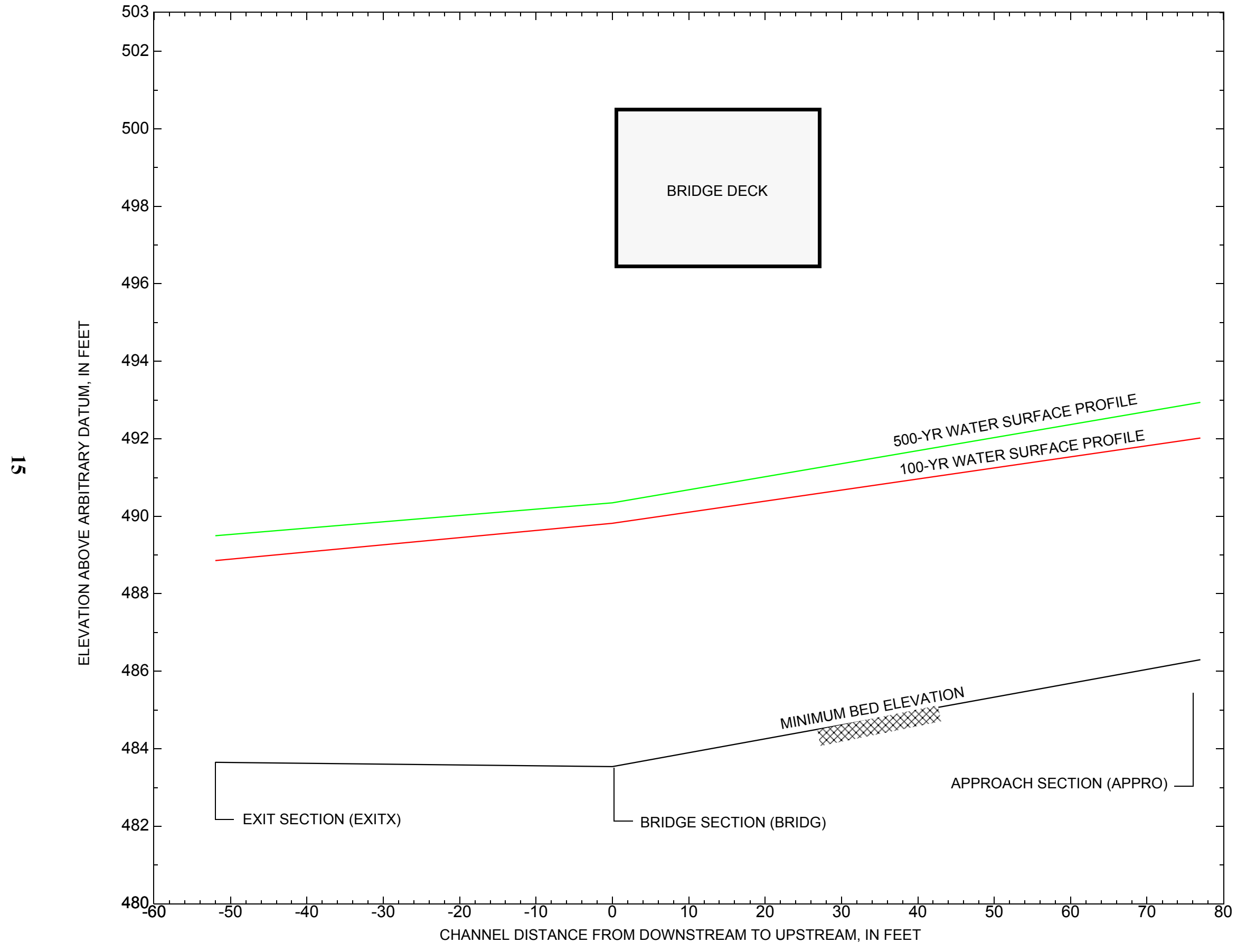

Figure 7. Water-surface profiles for the 100- and 500-yr discharges at structure WSTOTH00070026 on Town Highway 7, crossing Greendale Brook, Weston, Vermont. 


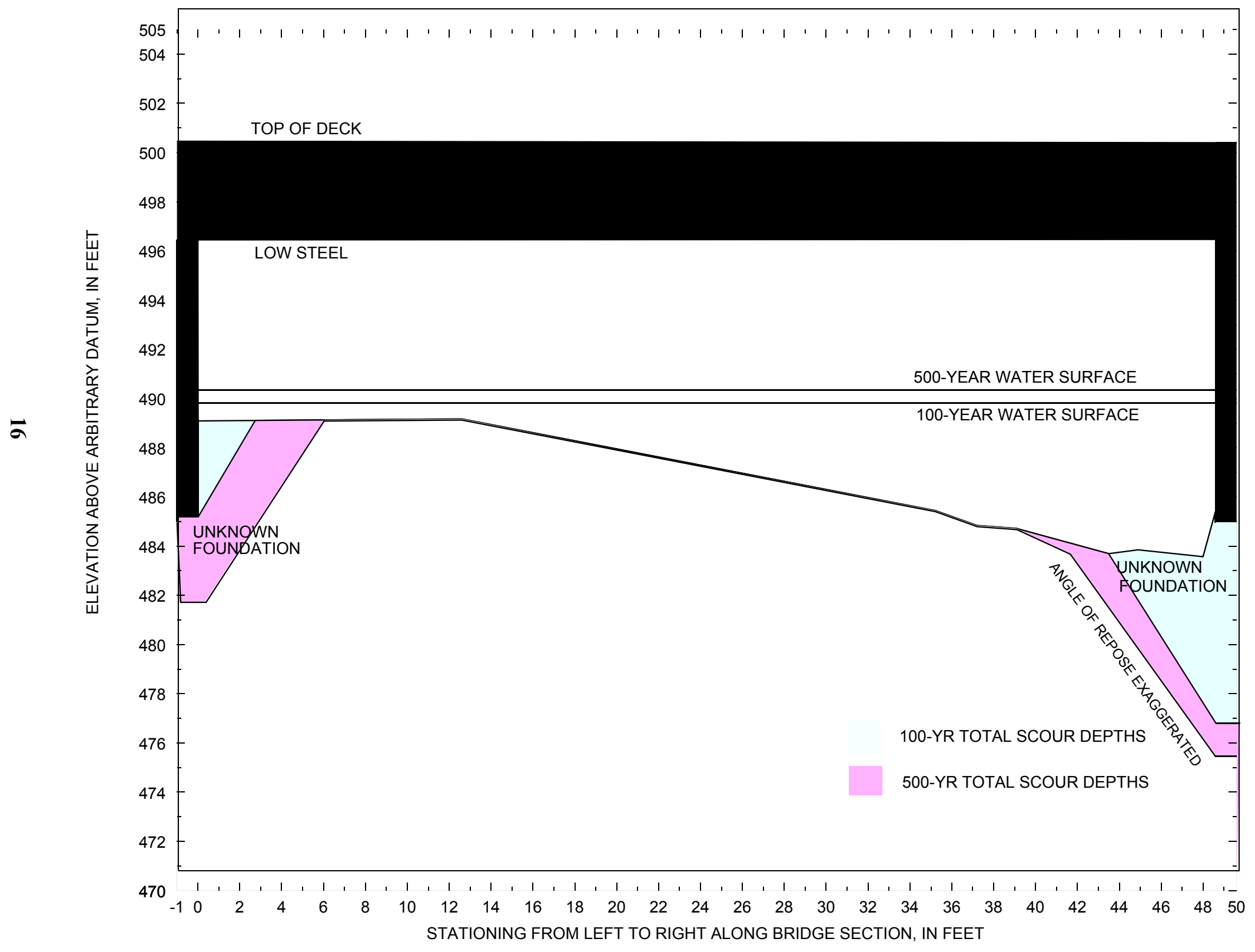

Figure 8. Scour elevations for the 100-year and 500-year discharges at structure WSTOTH00070026 on Town Highway 7, crossing Greendale Brook, Weston, Vermont. 
Table 1. Remaining footing/pile depth at abutments for the 100-year discharge at structure WSTOTH00070026 on Town Highway 7, crossing Greendale Brook, Weston, Vermont.

[VTAOT, Vermont Agency of Transportation; --,no data]

\begin{tabular}{|c|c|c|c|c|c|c|c|c|c|c|c|}
\hline Description & Station $^{1}$ & $\begin{array}{l}\text { VTAOT } \\
\text { minimum } \\
\text { low-chord } \\
\text { elevation } \\
\text { (feet) }\end{array}$ & $\begin{array}{c}\text { Surveyed } \\
\text { minimum } \\
\text { low-chord } \\
\text { elevation }{ }^{2} \\
\text { (feet) }\end{array}$ & $\begin{array}{c}\text { Bottom of } \\
\text { footing } \\
\text { elevation } \\
\text { (feet) }\end{array}$ & $\begin{array}{c}\text { Channel } \\
\text { elevation at } \\
\text { abutment/ } \\
\text { pier }^{2} \\
\text { (feet) }\end{array}$ & $\begin{array}{c}\text { Contraction } \\
\text { scour depth } \\
\text { (feet) }\end{array}$ & $\begin{array}{l}\text { Abutment } \\
\text { scour } \\
\text { depth } \\
\text { (feet) }\end{array}$ & $\begin{array}{l}\text { Pier } \\
\text { scour } \\
\text { depth } \\
\text { (feet) }\end{array}$ & $\begin{array}{l}\text { Depth of } \\
\text { total scour } \\
\text { (feet) }\end{array}$ & $\begin{array}{c}\text { Elevation of } \\
\text { scour }^{2} \\
\text { (feet) }\end{array}$ & $\begin{array}{c}\text { Remaining } \\
\text { footing/pile } \\
\text { depth } \\
\text { (feet) }\end{array}$ \\
\hline \multicolumn{12}{|c|}{100 -yr. discharge is 820 cubic-feet per second } \\
\hline Left abutment & 0.0 & -- & 496.5 & -- & 489.1 & 0.0 & 3.9 & -- & 3.9 & 485.2 & -- \\
\hline Right abutment & 48.6 & -- & 496.5 & -- & 485.4 & 0.0 & 8.6 & -- & 8.6 & 476.8 & -- \\
\hline
\end{tabular}

1.Measured along the face of the most constricting side of the bridge.

2.Arbitrary datum for this study.

Table 2. Remaining footing/pile depth at abutments for the 500-year discharge at structure WSTOTH00070026 on Town Highway 7, crossing Greendale Brook, Weston, Vermont.

[VTAOT, Vermont Agency of Transportation; --, no data]

\begin{tabular}{|c|c|c|c|c|c|c|c|c|c|c|c|}
\hline Description & Station $^{1}$ & $\begin{array}{l}\text { VTAOT } \\
\text { minimum } \\
\text { low-chord } \\
\text { elevation } \\
\text { (feet) }\end{array}$ & $\begin{array}{c}\text { Surveyed } \\
\text { minimum } \\
\text { low-chord } \\
\text { elevation } \\
\text { (feet) }\end{array}$ & $\begin{array}{l}\text { Bottom of } \\
\text { footing } \\
\text { elevation } \\
\text { (feet) }\end{array}$ & $\begin{array}{c}\text { Channel } \\
\text { elevation at } \\
\text { abutment/ } \\
\text { pier }^{2} \\
\text { (feet) }\end{array}$ & $\begin{array}{l}\text { Contraction } \\
\text { scour depth } \\
\text { (feet) }\end{array}$ & $\begin{array}{c}\text { Abutment } \\
\text { scour } \\
\text { depth } \\
\text { (feet) }\end{array}$ & $\begin{array}{l}\text { Pier } \\
\text { scour } \\
\text { depth } \\
\text { (feet) }\end{array}$ & $\begin{array}{l}\text { Depth of } \\
\text { total scour } \\
\text { (feet) }\end{array}$ & $\begin{array}{c}\text { Elevation of } \\
\text { scour }^{2} \\
\text { (feet) }\end{array}$ & $\begin{array}{c}\text { Remaining } \\
\text { footing/pile } \\
\text { depth } \\
\text { (feet) }\end{array}$ \\
\hline \multicolumn{12}{|c|}{500 -yr. discharge is 1150 cubic-feet per second } \\
\hline Left abutment & 0.0 & -- & 496.5 & -- & 489.1 & 0.0 & 7.3 & -- & 7.3 & 481.8 & -- \\
\hline Right abutment & 48.6 & -- & 496.5 & -- & 485.4 & 0.0 & 9.9 & -- & 9.9 & 475.5 & -- \\
\hline
\end{tabular}

1.Measured along the face of the most constricting side of the bridge.

2.Arbitrary datum for this study. 


\section{SELECTED REFERENCES}

Arcement, G.J., Jr., and Schneider, V.R., 1989, Guide for selecting Manning's roughness coefficients for natural channels and flood plains: U.S. Geological Survey Water-Supply Paper 2339, 38 p.

Barnes, H.H., Jr., 1967, Roughness characteristics of natural channels: U.S. Geological Survey Water-Supply Paper 1849,213 p.

Benson, M. A., 1962, Factors Influencing the Occurrence of Floods in a Humid Region of Diverse Terrain: U.S. Geological Survey WaterSupply Paper 1580-B, 64 p.

Brown, S.A. and Clyde, E.S., 1989, Design of riprap revetment: Federal Highway Administration Hydraulic Engineering Circular No. 11, Publication FHWA-IP-89-016, 156 p.

Federal Highway Administration, 1983, Runoff estimates for small watersheds and development of sound design: Federal Highway Administration Report FHWA-RD-77-158.

Federal Highway Administration, 1993, Stream Stability and Scour at Highway Bridges: Participant Workbook: Federal Highway Administration Report FHWA-HI-91-011.

Froehlich, D.C., 1989, Local scour at bridge abutments in Ports, M.A., ed., Hydraulic Engineering--Proceedings of the 1989 National Conference on Hydraulic Engineering: New York, American Society of Civil Engineers, p. 13-18.

Hayes, D.C.,1993, Site selection and collection of bridge-scour data in Delaware, Maryland, and Virginia: U.S. Geological Survey WaterResources Investigation Report 93-4017, 23 p.

Interagency Advisory Committee on Water Data, 1982, Guidelines for determining flood flow frequency: U.S. Geological Survey, Bulletin 17B of the Hydrology Subcommittee, 190 p.

Johnson, C.G. and Tasker, G.D.,1974, Progress report on flood magnitude and frequency of Vermont streams: U.S. Geological Survey OpenFile Report 74-130, 37 p.

Lagasse, P.F., Schall, J.D., Johnson, F., Richardson, E.V., Chang, F., 1995, Stream Stability at Highway Structures: Federal Highway Administration Hydraulic Engineering Circular No. 20, Publication FHWA-IP-90-014, 144 p.

Laursen, E.M., 1960, Scour at bridge crossings: Journal of the Hydraulics Division, American Society of Civil Engineers, v. 86, no. HY2, p. 39-53.

Potter, W. D., 1957a, Peak rates of runoff in the Adirondack, White Mountains, and Maine woods area, Bureau of Public Roads

Potter, W. D., 1957b, Peak rates of runoff in the New England Hill and Lowland area, Bureau of Public Roads

Richardson, E.V. and Davis, S.R., 1995, Evaluating scour at bridges: Federal Highway Administration Hydraulic Engineering Circular No. 18, Publication FHWA-IP-90-017, 204 p.

Richardson, E.V., Simons, D.B., and Julien, P.Y., 1990, Highways in the river environment: Federal Highway Administration Publication FHWA-HI-90-016.

Ritter, D.F., 1984, Process Geomorphology: W.C. Brown Co., Debuque, Iowa, 603 p.

Shearman, J.O., 1990, User's manual for WSPRO--a computer model for water surface profile computations: Federal Highway Administration Publication FHWA-IP-89-027, 187 p.

Shearman, J.O., Kirby, W.H., Schneider, V.R., and Flippo, H.N., 1986, Bridge waterways analysis model; research report: Federal Highway Administration Publication FHWA-RD-86-108, 112 p.

Talbot, A.N., 1887, The determination of water-way for bridges and culverts.

U.S. Department of Transportation, 1993, Stream stability and scour at highway bridges, Participant Workbook: Federal Highway Administration Publication FHWA HI-91-011.

U.S. Geological Survey, 1986, Weston, Vermont 7.5 Minute Series quadrangle map: U.S. Geological Survey Topographic Maps, Scale $1: 24,000$. 


\section{APPENDIX A: \\ WSPRO INPUT FILE}




\section{WSPRO INPUT FILE}

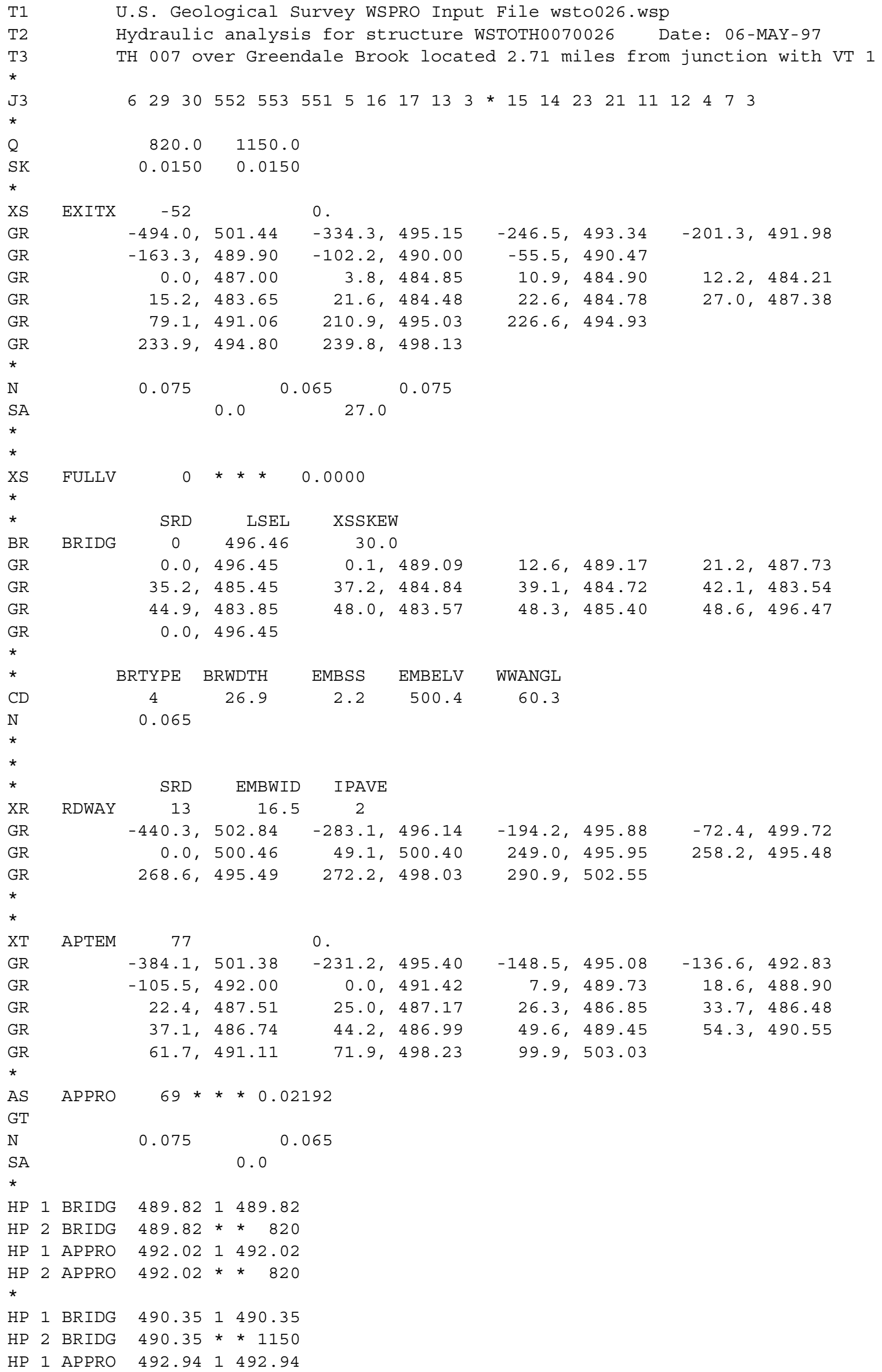




\section{APPENDIX B: \\ WSPRO OUTPUT FILE}




\section{WSPRO OUTPUT FILE}

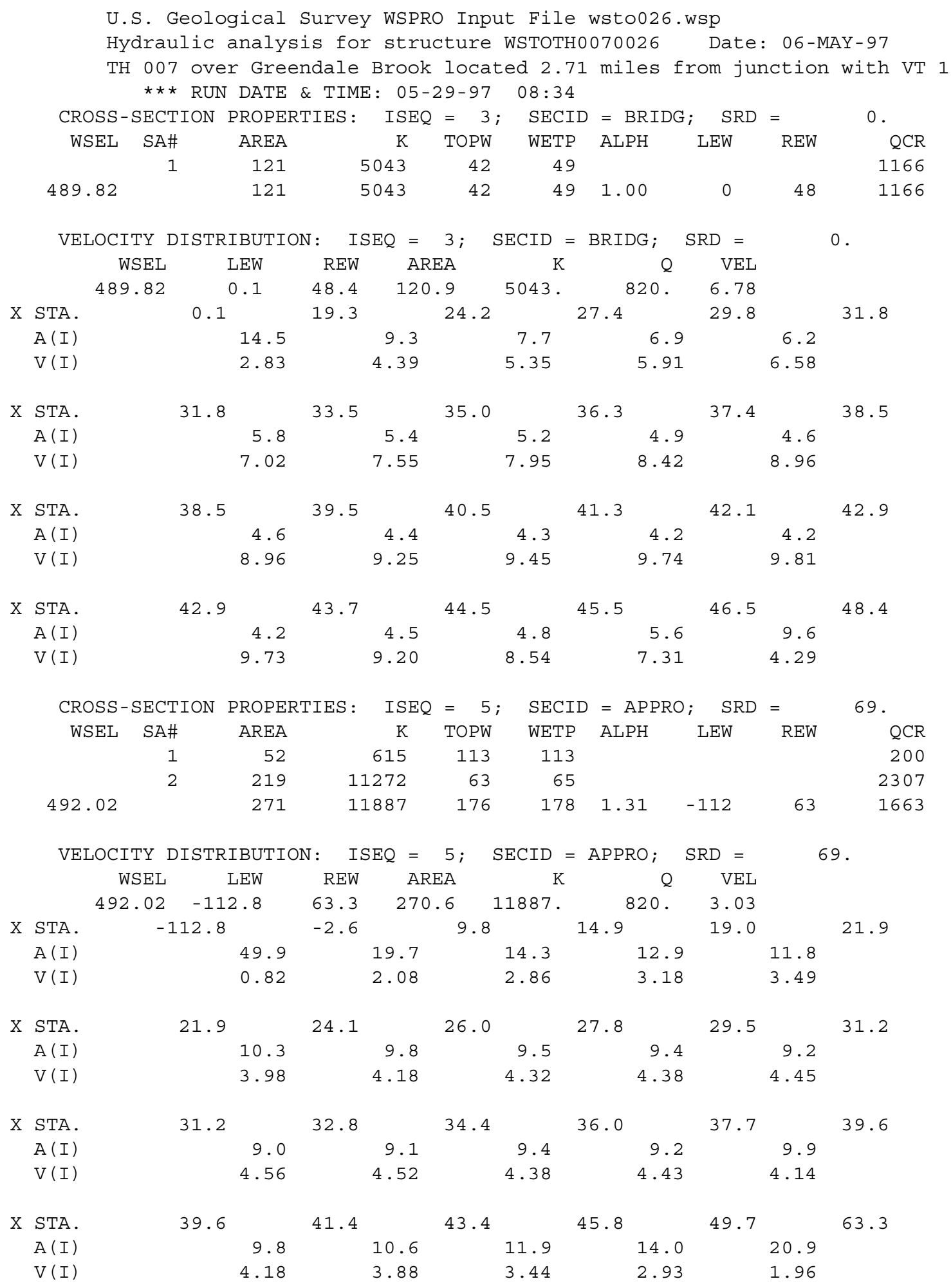




\section{WSPRO OUTPUT FILE (continued)}

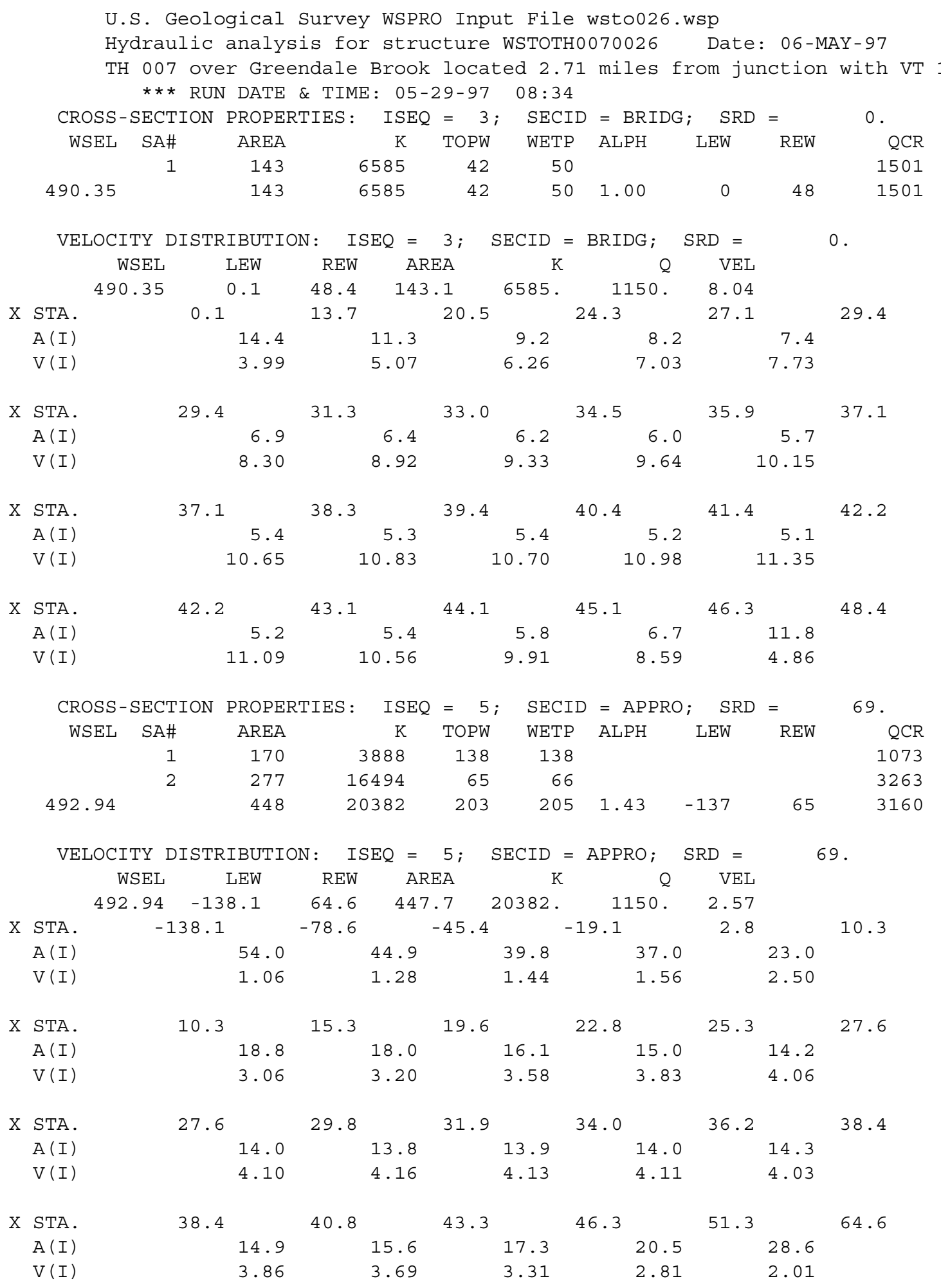




\section{WSPRO OUTPUT FILE (continued)}

U.S. Geological Survey WSPRO Input File wsto026.wsp Hydraulic analysis for structure WSTOTH0070026 Date: 06-MAY-97

TH 007 over Greendale Brook located 2.71 miles from junction with VT 1 *** RUN DATE \& TIME: 05-29-97 08:34

$\begin{array}{rrrrrrrrrr}\text { XSID : CODE } & \text { SRDL } & \text { LEW } & \text { AREA } & \text { VHD } & \text { HF } & \text { EGL } & \text { CRWS } & \text { Q } & \text { WSEL } \\ \text { SRD } & \text { FLEN } & \text { REW } & \text { K } & \text { ALPH } & \text { HO } & \text { ERR } & \text { FR\# } & \text { VEL } & \\ & & & & & & & & & \\ \text { EXITX:XS } & * * * * * * & -29 & 150 & 0.64 * * * * * & 489.50 & 488.20 & 820 & 488.86 \\ -51 * * * * * & 48 & 6690 & 1.38 * * * * * * * * * * * & 0.81 & 5.46 & \end{array}$

$==135$ CONVEYANCE RATIO OUTSIDE OF RECOMMENDED LIMITS.

\begin{tabular}{|c|c|c|c|c|c|c|c|c|c|}
\hline \multirow{3}{*}{ FULLV: FV } & \multicolumn{4}{|c|}{ "FULLV" } & \multicolumn{3}{|c|}{ KRATIO $=1.54$} & \multirow{2}{*}{\multicolumn{2}{|c|}{489.68}} \\
\hline & 52 & -42 & 224 & 0.31 & 0.514 & 490.00 & 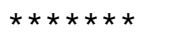 & & \\
\hline & 52 & 60 & 10310 & 1.52 & 0.00 & -0.01 & 0.54 & 3.65 & \\
\hline & $<<<<$ THE & \multicolumn{3}{|c|}{ ABOVE RESULTS REFLECT } & "NORMAL" & \multicolumn{2}{|c|}{ " (UNCONSTRICTED) } & \multicolumn{2}{|c|}{ FLOW $>>>>>$} \\
\hline$===135$ & CONVEYANCE & RATIO & "APPRO" & \multicolumn{2}{|c|}{ RECOMMENDED } & \multicolumn{2}{|c|}{ LIMITS. } & & \\
\hline \multirow{3}{*}{$A P P R O: A S$} & 69 & 4 & 122 & 0.70 & 0.91 & 491.11 & $\star \star \star \star \star \star * \star$ & 820 & 490.41 \\
\hline & 69 & 55 & 4938 & 1.00 & 0.19 & 0.01 & 0.77 & 6.72 & \\
\hline & $<<<<<\mathrm{THE}$ & \multicolumn{3}{|c|}{ ABOVE RESULTS REFLECT } & "NORMAL" & \multicolumn{2}{|c|}{ (UNCONSTRICTED) } & \multicolumn{2}{|c|}{ FLOW $>>>>>$} \\
\hline
\end{tabular}

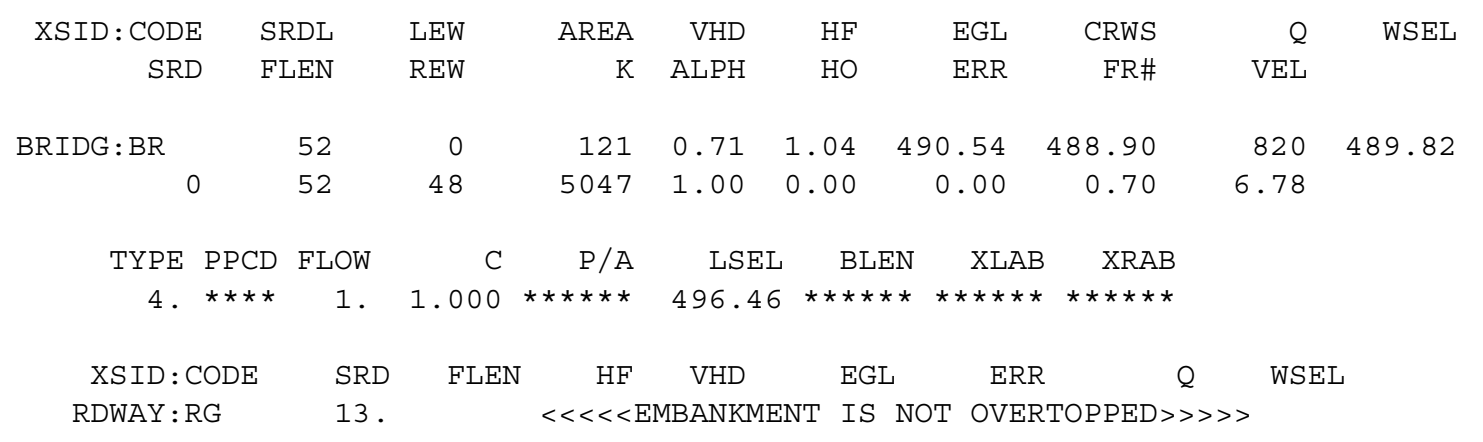

\begin{tabular}{|c|c|c|c|c|c|c|c|c|c|}
\hline XSID : CODE & SRDL & LEW & AREA & VHD & $\mathrm{HF}$ & EGL & CRWS & $Q$ & WSEI \\
\hline SRD & FLEN & REW & K & ALPH & $\mathrm{HO}$ & ERR & FR\# & VEL & \\
\hline APPRO:AS & 42 & -112 & 271 & 0.19 & 0.47 & 492.21 & 489.94 & 820 & 492.02 \\
\hline 69 & 42 & 63 & 11892 & 1.31 & 1.20 & 0.00 & 0.49 & 3.03 & \\
\hline $\mathrm{M}(\mathrm{G})$ & $\mathrm{M}(\mathrm{K})$ & KQ & XLKQ & $\mathrm{XRKC}$ & & ГEL & & & \\
\hline 0.051 & 0.192 & 9640. & -6 & 43 & 49 & 1.77 & & & \\
\hline
\end{tabular}

FIRST USER DEFINED TABLE.

\begin{tabular}{|c|c|c|c|c|c|c|c|c|}
\hline XSID : CODE & SRD & LEW & REW & $Q$ & $\mathrm{~K}$ & AREA & VEL & WSEL \\
\hline EXITX : XS & -52. & -30. & 48 & 820. & 6690. & 150 & 5.46 & 488.86 \\
\hline FULLV : FV & 0 & -43. & 60. & 820. & 10310 . & 224 . & 3.65 & 489.68 \\
\hline BRIDG : BR & 0 . & 0 . & 48. & 820. & 5047. & 121. & 6.78 & 489.82 \\
\hline RDWAY : RG & \multicolumn{3}{|c|}{$13 . * * * * * * * * * * * * * *$} & \multicolumn{3}{|c|}{$0 . * * * * * * * * * * * * * * * * * *$} & \multicolumn{2}{|c|}{$2.00 * * * * * * * *$} \\
\hline APPRO : AS & 69. & -113. & 63. & 820. & 11892 . & 271 & 3.03 & 492.02 \\
\hline
\end{tabular}

SECOND USER DEFINED TABLE.

$\begin{array}{lccccccccc}\text { XSID : CODE } & \text { CRWS } & \text { FR\# } & \text { YMIN } & \text { YMAX } & \text { HF } & \text { HO } & \text { VHD } & \text { EGL } & \text { WSEL } \\ \text { EXITX:XS } & 488.20 & 0.81 & 483.65 & 501.44 * * * * * * * * * * * & 0.64 & 489.50 & 488.86 \\ \text { FULLV:FV } & * * * * * * * & 0.54 & 483.65 & 501.44 & 0.51 & 0.00 & 0.31 & 490.00 & 489.68 \\ \text { BRIDG : BR } & 488.90 & 0.70 & 483.54 & 496.47 & 1.04 & 0.00 & 0.71 & 490.54 & 489.82 \\ \text { RDWAY :RG } & * * * * * * * * * * * * * * * & 495.48 & 502.84 * * * * * * * * * * * * * * * * * * * * * * * * * * * * * \\ \text { APPRO:AS } & 489.94 & 0.49 & 486.30 & 502.85 & 0.47 & 1.20 & 0.19 & 492.21 & 492.02\end{array}$




\section{WSPRO OUTPUT FILE (continued)}

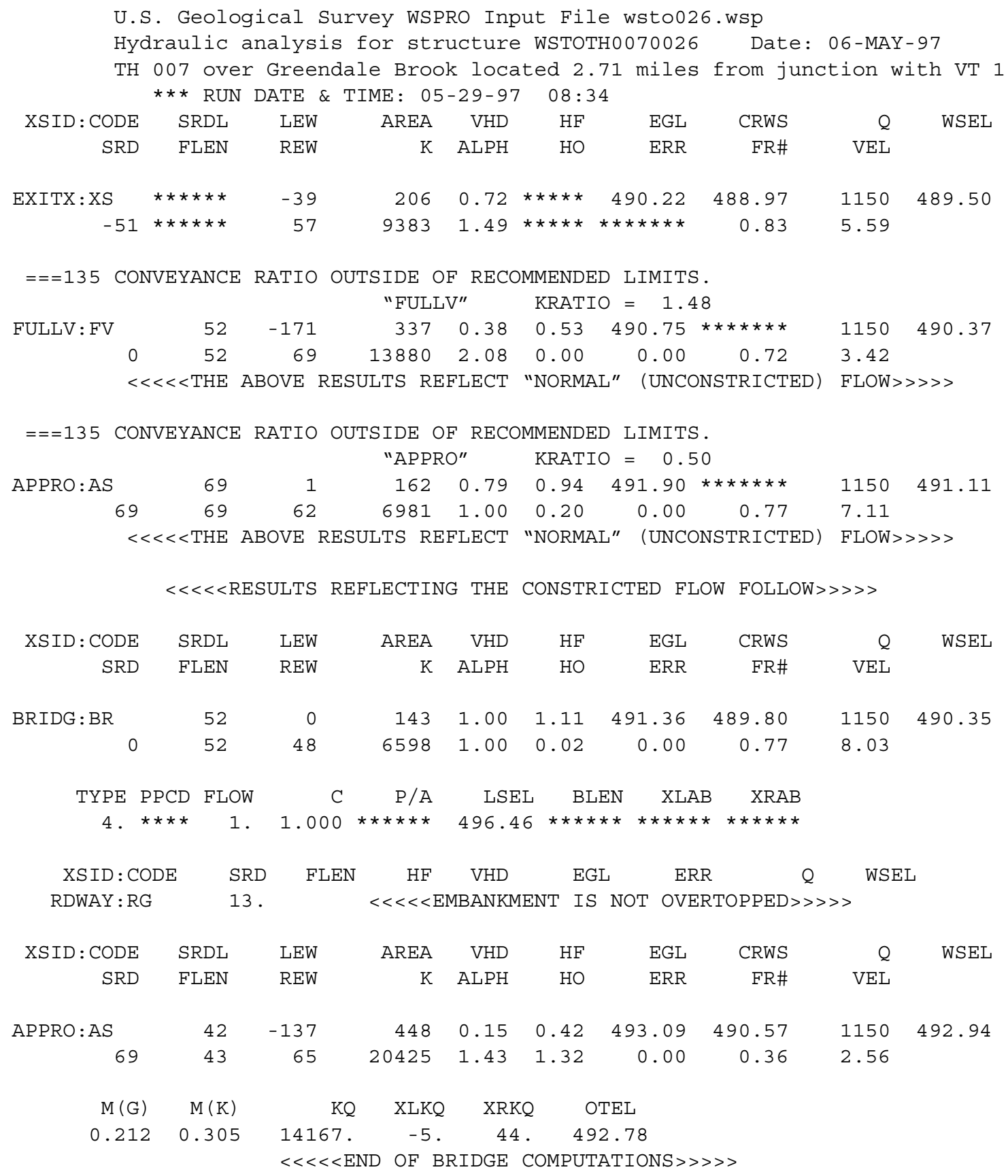

FIRST USER DEFINED TABLE.

\begin{tabular}{lrrrrrrrr} 
XSID $:$ CODE & SRD & LEW & REW & $Q$ & K & AREA & VEL & WSEL \\
EXITX $:$ XS & -52. & -40. & 57. & 1150. & 9383. & 206. & 5.59 & 489.50 \\
FULLV $:$ FV & 0. & -172. & 69. & 1150. & 13880. & 337. & 3.42 & 490.37 \\
BRIDG $:$ BR & 0. & 0. & 48. & 1150. & 6598. & 143. & 8.03 & 490.35 \\
RDWAY $:$ RG & \multicolumn{2}{c}{$13 . * * * * * * * * * * * * *$} & $0 . * * * * * * * * * * * * * * *$ & $2.00 * * * * * * *$ \\
APPRO : AS & 69. & -138. & 65. & 1150. & 20425. & 448. & 2.56 & 492.94
\end{tabular}

SECOND USER DEFINED TABLE.

$\begin{array}{lccccccccc}\text { XSID :CODE } & \text { CRWS } & \text { FR\# } & \text { YMIN } & \text { YMAX } & \text { HF } & \text { HO } & \text { VHD } & \text { EGL } & \text { WSEL } \\ \text { EXITX:XS } & 488.97 & 0.83 & 483.65 & 501.44 * * * * * * * * * * * & 0.72 & 490.22 & 489.50 \\ \text { FULLV:FV } & * * * * * * * & 0.72 & 483.65 & 501.44 & 0.53 & 0.00 & 0.38 & 490.75 & 490.37 \\ \text { BRIDG :BR } & 489.80 & 0.77 & 483.54 & 496.47 & 1.11 & 0.02 & 1.00 & 491.36 & 490.35 \\ \text { RDWAY:RG } & * * * * * * * * * * * * * * * & 495.48 & 502.84 * * * * * * * * * * * * * * * * * * * * * * * * * * * * * * \\ \text { APPRO :AS } & 490.57 & 0.36 & 486.30 & 502.85 & 0.42 & 1.32 & 0.15 & 493.09 & 492.94\end{array}$




\section{APPENDIX C:}

\section{BED-MATERIAL PARTICLE-SIZE DISTRIBUTION}




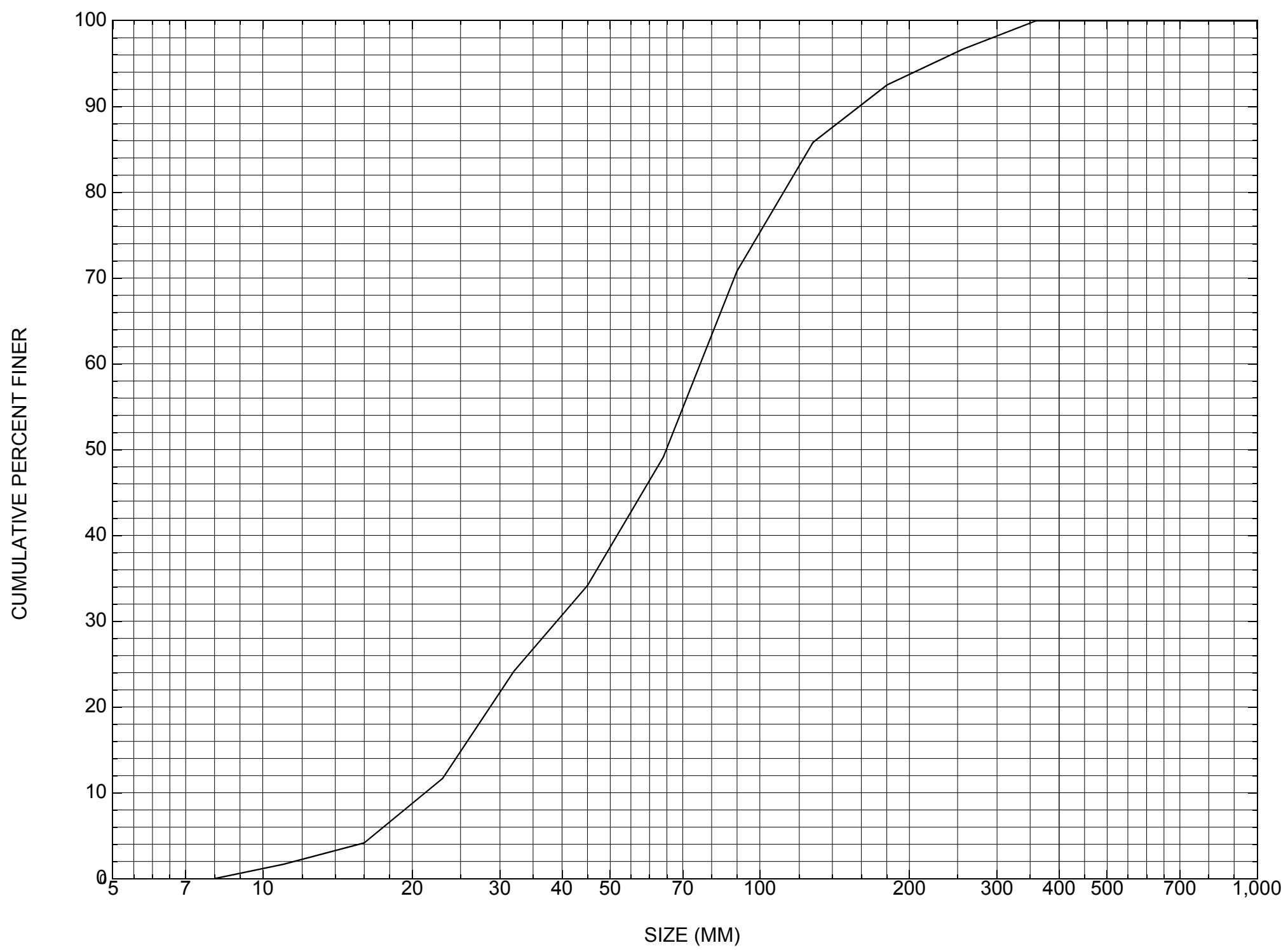

Appendix C. Bed material particle-size distribution for a pebble count in the channel approach of structure WSTOTH00070026, in Weston, Vermont. 


\section{APPENDIX D: \\ HISTORICAL DATA FORM}




\section{Structure Number wSTOTH00070026}

\section{General Location Descriptive}

Data collected by (First Initial, Full last name) $\mathbf{M}$. IVANOFF

Date $(M M / D D / Y Y) \_\mathbf{0 4} / \underline{07} / \underline{95}$

Highway District Number (I - 2; nn) $\mathbf{0 2}$

Town (FIPS place code; I - 4; nnnnn) $\mathbf{8 2 0 0 0}$

Waterway ( $($ - 6) GREENDALE BROOK

Route Number TH007

Topographic Map Weston

Latitude (I - 16; nnnn.n) $\mathbf{4 3 2 0 8}$
County (FIPS county code; I - 3; nnn)

Mile marker (I - 11; nnn.nnn) $\mathbf{0 0 0 0 0 0}$

Road Name (I - 7): -

Vicinity (I - 9) 2.71 MI TO JCT W VT100

Hydrologic Unit Code: $\mathbf{0 1 0 8 0 1 0 7}$

Longitude (i - 17; nnnnn.n) $\mathbf{7 2 4 8 9}$

\section{Select Federal Inventory Codes}

FHWA Structure Number (I - 8) $\mathbf{1 0 1 4 2 1 0 0 2 6 1 4 2 1}$

Maintenance responsibility $(I-21 ; n n) \_$03 _ Maximum span length $(I-48$; $n n n n) \underline{\mathbf{0 0 5 0}}$

Year built (I - 27; YYYY) 1940

Structure length (I - 49; nnnnnn) $\underline{\mathbf{0 0 0 0 5 2}}$

Average daily traffic, ADT (I - 29; nnnnnn) 000010 Deck Width (I- 52; nn.n) 165

Year of ADT (I - 30; YY) $\mathbf{9 1}$

Channel \& Protection $(I-61 ; n) \underline{\mathbf{6}}$

Opening skew to Roadway $(I-34 ; n n) \quad \mathbf{3 0}$

Waterway adequacy $(I-71 ; n)$

Operational status $(I-41 ; X) \quad \mathbf{P}$

Underwater Inspection Frequency $(I-92 B ; X Y Y) \_\mathbf{N}$

Structure type (I - 43; nnn) $\mathbf{3 0 2}$

Year Reconstructed (I - 106) $\mathbf{0 0 0 0}$

Approach span structure type (I - 44; nnn) $\mathbf{0 0 0}$ Clear span (nnn.n ft) _ _

Number of spans (I - 45; nnn) $\mathbf{0 0 1}$

Vertical clearance from streambed (nnn.n ft) $\underline{\mathbf{0 1 0 . 0}}$

Number of approach spans (I - 46; nnnn) $\mathbf{0 0 0 0}$

Waterway of full opening $\left(n n n . n \mathrm{ft}^{2}\right)$

Comments:

The structural inspection report of $09 / 16 / 93$ indicates states that the structure is a single span, steel beam type bridge with a bare concrete deck. Both abutments are concrete, and have minor hairline cracks and stains reported. The right abutment footing is exposed along the upstream end but is not undermined. The waterway takes a moderate to sharp turn into the skewed structure. All of the flow is along the right abutment. There is boulder fill placed along the upstream right abutment side. The footing along the left abutment is not in view, due to a gravel point bar with vegetation growth. The banks upstream are well protected from erosion. 


\section{Bridge Hydrologic Data}

Is there hydrologic data available? $\underline{\mathbf{N}}$ if No, type ctrl-n $h \quad$ VTAOT Drainage area $\left(m i^{2}\right)$ : -

Terrain character:

Stream character \& type: -

Streambed material:

Discharge Data (cfs):

$$
\begin{aligned}
& Q_{2.33}- \\
& Q_{50}-
\end{aligned}
$$

Record flood date $(M M / D D / Y Y)$ :

Estimated Discharge (cfs): Ice conditions (Heavy, Moderate, Light) : -

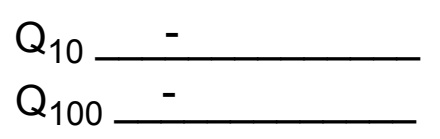

$$
\begin{aligned}
& Q_{25}- \\
& Q_{500}-
\end{aligned}
$$

Water surface elevation $(f t):-$

The stage increases to maximum highwater elevation (Rapidly, Not rapidly):

The stream response is (Flashy, Not flashy):

Describe any significant site conditions upstream or downstream that may influence the stream's stage: -

Watershed storage area (in percent): _ _ \%

The watershed storage area is: - (1-mainly at the headwaters; 2- uniformly distributed; 3-immediatly upstream oi the site)

Water Surface Elevation Estimates for Existing Structure:

\begin{tabular}{|l|l|l|l|l|l|}
\hline Peak discharge frequency & $Q_{2.33}$ & $Q_{10}$ & $Q_{25}$ & $Q_{50}$ & $Q_{100}$ \\
Water surface elevation (ft)) & - & - & - & - & - \\
Velocity (ft/sec) & - & - & - & - & - \\
\hline
\end{tabular}

Long term stream bed changes: -

Is the roadway overtopped below the $\mathrm{Q}_{100}$ ? (Yes, No, Unknown): $\mathbf{U}$ Frequency: Relief Elevation (ft): Discharge over roadway at $Q_{100}\left(f^{3} / \mathrm{sec}\right)$ :

Are there other structures nearby? (Yes, No, Unknown): $\underline{\mathbf{U}}$ Upstream distance (miles): Town: If No or Unknown, type ctrl-n os Highway No. : Structure No. : Year Built:

Clear span (ft): Clear Height $(f t)$ : Full Waterway $\left(f^{2}\right)$ : 
Downstream distance (miles): Town: Year Built:

Highway No. : Structure No. : Structure Type:

Clear span (ft): Clear Height $(f t)$ : Full Waterway $\left(f^{2}\right)$ : -

Comments:

\section{USGS Watershed Data}

Watershed Hydrographic Data

Drainage area (DA) 3.13

Watershed storage (ST) $\mathrm{mi}^{2}$ Lake/pond/swamp area $\mathrm{mi}^{2}$

Bridge site elevation 1654 $\mathrm{ft}$ $\%$

Main channel length $\mathbf{2 . 3 6}$ $\mathrm{mi}$

$10 \%$ channel length elevation 1693 $\mathrm{ft} \quad 85 \%$ channel length elevation $\mathrm{ft}$

Main channel slope $(S)$

(S) 322.81 $\mathrm{ft} / \mathrm{mi}$

Watershed Precipitation Data

Average site precipitation in Average headwater precipitation in

Maximum 2yr-24hr precipitation event $(124,2)$ in

Average seasonal snowfall (Sn) $\mathrm{ft}$ 


\section{Bridge Plan Data}

Are plans available? $\mathbf{N} \quad$ If no, type ctrl-n pl Date issued for construction (MM / YYYY):

Project Number

Minimum channel bed elevation:

Low superstructure elevation: USLAB DSLAB USRAB DSRAB Benchmark location description:

There is no benchmark elevation data available.

Reference Point (MSL, Arbitrary, Other):

Datum (NAD27, NAD83, Other):

Foundation Type: 4

If 1: Footing Thickness

If 2: Pile Type:

If 3: Footing bottom elevation:

Is boring information available? $\mathbf{N}$

Foundation Material Type: $\mathbf{3}$

(1-Spreadfooting; 2-Pile; 3- Gravity; 4-Unknown)

Footing bottom elevation: -

Briefly describe material at foundation bottom elevation or around piles:

There is no foundation material information available.

Comments:

There are no bridge plans available. 


\section{Cross-sectional Data}

Is cross-sectional data available? $\mathbf{N}$ If no, type ctrl-n xs

Source (FEMA, VTAOT, Other)? -

Comments:

There is no cross section information available.

\begin{tabular}{|l|l|l|l|l|l|l|l|l|l|l|l|}
\hline Station & - & - & - & - & - & - & - & - & - & - & - \\
\hline Feature & - & - & - & - & - & - & - & - & - & - & - \\
\hline $\begin{array}{l}\text { Low cord } \\
\text { elevation }\end{array}$ & - & - & - & - & - & - & - & - & - & - & - \\
\hline $\begin{array}{l}\text { Bed } \\
\text { elevation }\end{array}$ & - & - & - & - & - & - & - & - & - & - & - \\
\hline $\begin{array}{l}\text { Low cord to } \\
\text { bed length }\end{array}$ & - & - & - & - & - & - & - & - & - & - & - \\
\hline Station & - & - & - & - & - & - & - & - & - & - & - \\
\hline Feature & - & - & - & - & - & - & - & - & - & - & - \\
\hline $\begin{array}{l}\text { Low cord } \\
\text { elevation }\end{array}$ & - & - & - & - & - & - & - & - & - & - & - \\
\hline $\begin{array}{l}\text { Bed } \\
\text { elevation }\end{array}$ & - & - & - & - & - & - & - & - & - & - & - \\
\hline $\begin{array}{l}\text { Low cord to } \\
\text { bed length }\end{array}$ & - & - & - & - & - & - & - & - & - & - & - \\
\hline
\end{tabular}

Source (FEMA, VTAOT, Other)? $\mathbf{N}$

Comments: There is no cross section information available.

\begin{tabular}{|l|l|l|l|l|l|l|l|l|l|l|l|}
\hline Station & - & - & - & - & - & - & - & - & - & - & - \\
\hline Feature & - & - & - & - & - & - & - & - & - & - & - \\
\hline $\begin{array}{l}\text { Low cord } \\
\text { elevation }\end{array}$ & - & - & - & - & - & - & - & - & - & - & - \\
\hline $\begin{array}{l}\text { Bed } \\
\text { elevation }\end{array}$ & - & - & - & - & - & - & - & - & - & - & - \\
\hline $\begin{array}{l}\text { Low cord to } \\
\text { bed length }\end{array}$ & - & - & - & - & - & - & - & - & - & - & - \\
\hline Station & - & - & - & - & - & - & - & - & - & - & - \\
\hline Feature & - & - & - & - & - & - & - & - & - & - & - \\
\hline $\begin{array}{l}\text { Low cord } \\
\text { elevation }\end{array}$ & - & - & - & - & - & - & - & - & - & - & - \\
\hline $\begin{array}{l}\text { Bed } \\
\text { elevation }\end{array}$ & - & - & - & - & - & - & - & - & - & - & - \\
\hline $\begin{array}{l}\text { Low cord to } \\
\text { bed length }\end{array}$ & - & - & - & - & - & - & - & - & - & - & - \\
\hline
\end{tabular}




\section{APPENDIX E: \\ LEVEL I DATA FORM}


U. S. Geological Survey

Bridge Field Data Collection and Processing Form

Qa/Qc Check by: EW

Date: $10 / 3 / 96$

\section{Structure Number WSTOTH00070026} Computerized by: $\underline{\mathbf{E W}}$ Date: $\underline{\mathbf{1 0 / 3} / 96}$

Reviewd by: LKS Date: $\underline{\mathbf{0 5} / \mathbf{2 0} / \mathbf{9 7}}$

\section{A. General Location Descriptive}

1. Data collected by (First Initial, Full last name) $\underline{\mathbf{R}}$. HAMMOND

Date $(M M / D D / Y Y) \underline{08} / \underline{19} / 1996$

2. Highway District Number $\mathbf{0 2}$

County WINDSOR 027

Waterway (l - 6) GREENDALE BROOK

Route Number $\mathbf{T H 0 0 7}$

3. Descriptive comments:

The bridge is located 2.71 miles from junction with VT 100, and 0.5 miles upstream of the junction with a road along Jenny Collidge Brook.
Mile marker 000000

Town WESTON 82000

Road Name -

Hydrologic Unit Code: $\mathbf{0 1 0 8 0 1 0 7}$

\section{B. Bridge Deck Observations}
4. Surface cover... LBUS 6
RBUS 6
LBDS 6
RBDS 6
Overall 6

(2b us,ds,lb,rb: 1- Urban; 2- Suburban; 3- Row crops; 4- Pasture; 5- Shrub- and brushland; 6- Forest; 7- Wetland)
5. Ambient water surface... US 2
UB 1
DS $\underline{2}$
(1- pool; 2- riffle)

6. Bridge structure type 1 (1- single span; 2- multiple span; 3- single arch; 4- multiple arch; 5-cylindrical culvert; 6- box culvert; or 7- other)
7. Bridge length $\mathbf{5 2}$
(feet)
Span length $\underline{\mathbf{5 0}}$
(feet)
Bridge width 16.5 (feet)

\section{Road approach to bridge:}
8. LB 0
RB 0
( 0 even, 1- lower, 2- higher)
9. LB_2
RB $\underline{2}$
(1-Paved, 2- Not paved)

10. Embankment slope (run / rise in feet / foot)

US left

2.1:1

US right 2.3:1

LBUS

\begin{tabular}{|c|c|c|c|}
\hline \multicolumn{2}{|c|}{ Protection } & \multirow{2}{*}{ 13.Erosion } & 14.Severity \\
\cline { 1 - 2 } 11.Type & 12.Cond. & & \\
\hline
\end{tabular}

RBUS

RBDS

LBDS

\begin{tabular}{l|l|}
\hline $\mathbf{0}$ & - \\
\hline $\mathbf{0}$ & - \\
\hline $\mathbf{0}$ & - \\
\hline $\mathbf{0}$ & - \\
\hline
\end{tabular}

\begin{tabular}{l}
$\mathbf{0}$ \\
\hline $\mathbf{2}$ \\
\hline $\mathbf{0}$
\end{tabular}

Bank protection types: 0- none; 1- < 12 inches,

2- $<36$ inches; 3- $<48$ inches

4- < 60 inches; 5- wall / artificial levee

Bank protection conditions: 1- good; 2- slumped;

3- eroded; 4- failed

Erosion: 0 - none; 1- channel erosion; 2 -

road wash; 3- both; 4- other

Erosion Severity: 0 - none; 1- slight; 2- moderate; 3- severe

\section{Channel approach to bridge (BF):}

15. Angle of approach: $\mathbf{1 0}$

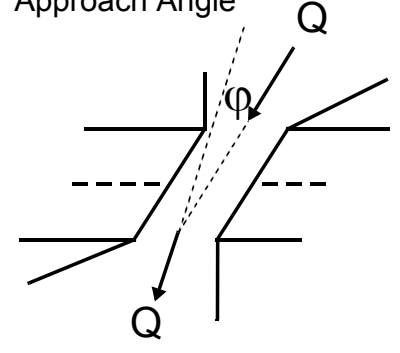

17. Channel impact zone 1 :

Where? RB (LB, RB)

Range? 0 feet US

Channel impact zone 2:

Where? LB (LB, RB)

Range? $\underline{30}$ feet $\underline{\mathbf{D S}}$ (US, UB, DS) to $\underline{\mathbf{1 0 0}}$ feet $\underline{\mathbf{D S}}$

Impact Severity: 0- none to very slight; 1-Slight; 2- Moderate; 3- Severe
16. Bridge skew: $\mathbf{5 0}$

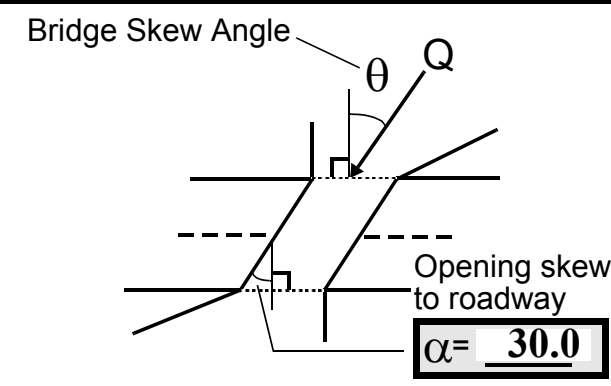

Exist? $\mathbf{Y}(Y$ or $N)$

Severity 2

US, UB, DS) to $\underline{\mathbf{2 5}}$ feet $\underline{\mathbf{U S}}$

Exist? $\mathbf{Y}(\mathrm{Y}$ or $N)$

Severity $\underline{\mathbf{0}}$ 
18. Bridge Type: 4

1a- Vertical abutments with wingwalls

$1 \mathrm{~b}$ - Vertical abutments without wingwalls

2- Vertical abutments and wingwalls, sloping embankment Wingwalls perpendicular to abut. face

3- Spill through abutments

4- Sloping embankment, vertical wingwalls and abutments

Wingwall angle less than $90^{\circ}$.

19. Bridge Deck Comments (surface cover variations, measured bridge and span lengths, bridge type variations, approach overflow width, etc.)

\#7: Measured bridge length $=51.4$ feet; bridge span $=49.4$ feet; road width $=14$ feet and bridge width $=16.5$ feet.

\#8: Road is even on both approaches for 75 feet, then dips below bridge deck.

\#15/ 16: Based on general channel path the ambient channel meanders from side to side throughout the reach.

\section{Upstream Channel Assessment}

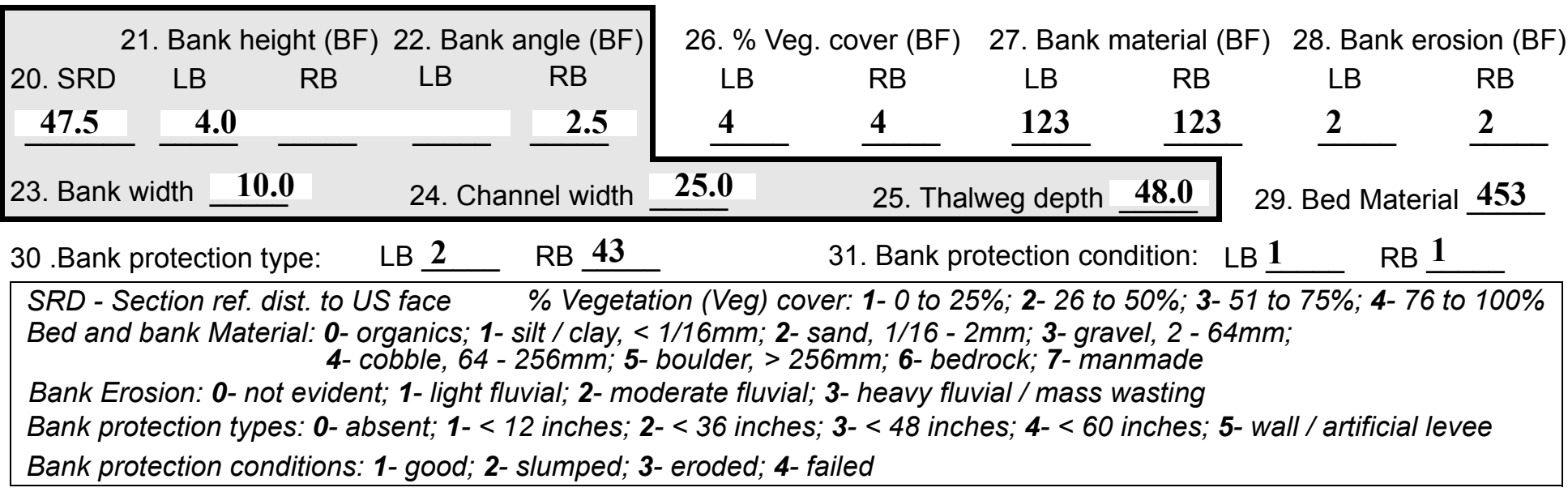

32. Comments (bank material variation, minor inflows, protection extent, etc.):

\#28: Moderate bank erosion extends along both banks from at least 250 feet upstream to 5 feet upstream. The most severely eroded area is at 175 feet upstream. Bank erosion is result of medium to bank full flows.

Drop structures, logs placed in $V$ configuration by the Forest Service to make pools for fish to habitat, are located at 72 feet upstream and 225 feet upstream of the bridge.

The point bar acts as the left bank, during the time of inspection and other low flows. 

feet US feet $\underline{\text { DS }}$ (US, UB, DS) positioned 0 $\%$ LB to $\mathbf{5 0}$ $\% R B$

37. Material: $\mathbf{3 4 5}$

38. Point or side bar comments (Circle Point or Side; Note additional bars, material variation, status, etc.):

The point bar is vegetated with brush and small diameter trees upstream and downstream of the bridge. Underneath the bridge the vegetation is annual. The sediment that comprises the pointbar under the bridge is loose and unconsolidated. Another point bar, composed of gravel and cobbles, exists from 185 feet upstream to 115 feet upstream. It is 15 feet wide at 135 feet upstream. The point bar is positioned $0 \% \mathrm{LB}$ to $40 \% \mathrm{RB}$.

39. Is a cut-bank present? $\mathbf{N}$ ( $Y$ or if $N$ type ctrl-n $c b)$

40. Where? (LB or RB)

41. Mid-bank distance: -

42. Cut bank extent: feet (US, UB) to feet (US, UB, DS)

43. Bank damage: = (1- eroded and/or creep; 2- slip failure; 3- block failure)

44. Cut bank comments (eg. additional cut banks, protection condition, etc.):

There are no cut-banks upstream at this bridge.

\section{Is channel scour present? $\mathbf{Y}$ (Y or if $N$ type ctrl-n cs) 46. Mid-scour distance: 10 UB}
47. Scour dimensions: Length $\mathbf{3 0}$
Width 7
Depth : 1.5
Position $\underline{80} \%$ LB to $100 \%$ RB

48. Scour comments (eg. additional scour areas, local scouring process, etc.):

The scour hole extends from 0 feet upstream to 10 feet downstream.

There is also local scour behind boulders.

49. Are there major confluences? $\mathbf{N}$

51. Confluence 1: Distance -

Confluence 2: Distance -

54. Confluence comments (eg. confluence name):

There are no major confluences upstream at this site.
( $Y$ or if $N$ type ctrl-n mc)

52. Enters on ( $L B$ or $R B)$

Enters on (LB or $R B)$
50. How many? -

53. Type(1-perennial; 2- ephemeral)

Type (1- perennial; 2- ephemeral)

\section{Under Bridge Channel Assessment}

55. Channel restraint (BF)? LB 2

56. Height (BF)
LB RB
$\mathbf{2 2 . 0}-$
58. Bank width (BF) =-
(1- natural bank; 2- abutment; 3- artificial levee)

Bed and bank Material: 0- organics; 1- silt / clay, < 1/16mm; 2- sand, 1/16 - 2mm; 3- gravel, 2 - 64mm; 4- cobble, 64 - 256mm; 5- boulder, > 256mm; 6- bedrock; 7- manmade

Bank Erosion: 0- not evident; 1- light fluvial; 2- moderate fluvial; 3- heavy fluvial / mass wasting

64. Comments (bank material variation, minor inflows, protection extent, etc.):

342 
65. Debris and Ice Is there debris accumulation?

(Yor $N)$ 66. Where? $\underline{Y}$

(1- Upstream; 2- At bridge; 3- Both)

67. Debris Potential $\underline{3}$

(1- Low; 2- Moderate; 3- High)

68. Capture Efficiency 2

(1-Low; 2- Moderate; 3- High)

69. Is there evidence of ice build-up? 1 ( $Y$ or $N)$

Ice Blockage Potential $\underline{Y}$

(1-Low; 2- Moderate; 3- High)

70. Debris and Ice Comments:

1

The base of trees and exposed roots show scars from ice and/ or debris impact.

\begin{tabular}{|l|c|c|c|c|c|c|c|c|}
\hline Abutments & $\begin{array}{c}71 . \text { Attack } \\
\angle \text { (BF) }\end{array}$ & $\begin{array}{c}\text { 72. Slope } \angle \\
\text { (Qmax) }\end{array}$ & $\begin{array}{c}\text { 73. Toe } \\
\text { loc. (BF) }\end{array}$ & $\begin{array}{c}\text { 74. Scour } \\
\text { Condition }\end{array}$ & $\begin{array}{c}75 . \text { Scour } \\
\text { depth }\end{array}$ & $\begin{array}{c}\text { 76. Exposure } \\
\text { depth }\end{array}$ & 77. Material & 78. Length \\
\hline LABUT & & - & $\mathbf{9 0}$ & $\mathbf{2}$ & $\mathbf{0}$ & - & - & $\mathbf{9 0 . 0}$ \\
\hline RABUT & $\mathbf{1}$ & $\mathbf{3 0}$ & $\mathbf{9 0}$ & & & $\mathbf{2}$ & $\mathbf{2}$ & $\mathbf{4 2 . 0}$ \\
\hline
\end{tabular}

Pushed: $L B$ or RB

Toe Location (Loc.): 0- even, 1- set back, 2- protrudes

Scour cond.: 0- not evident; 1- evident (comment); 2- footing exposed; 3-undermined footing; 4- piling exposed; 5- settled; 6- failed

Materials: 1- Concrete; 2- Stone masonry or drywall; 3- steel or metal; 4- wood

79. Abutment comments (eg. undermined penetration, unusual scour processes, debris, etc.):

1.5

0.1

1

\#76: Scour is about 0.1 feet below top of footing.

80. Wingwalls:

Exist? Material? Scour Scour Exposure Angle? Length? Condition? depth? depth?

USLWW:

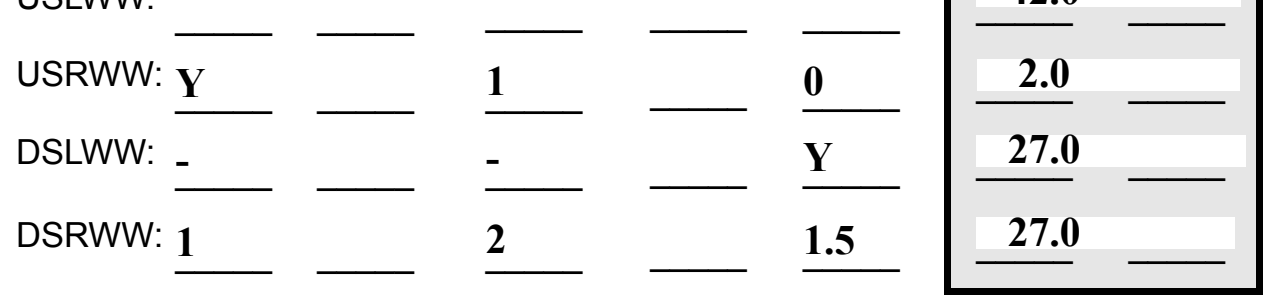

Wingwall materials: 1- Concrete; 2- Stone masonry or drywall; 3- steel or metal; 4- wood

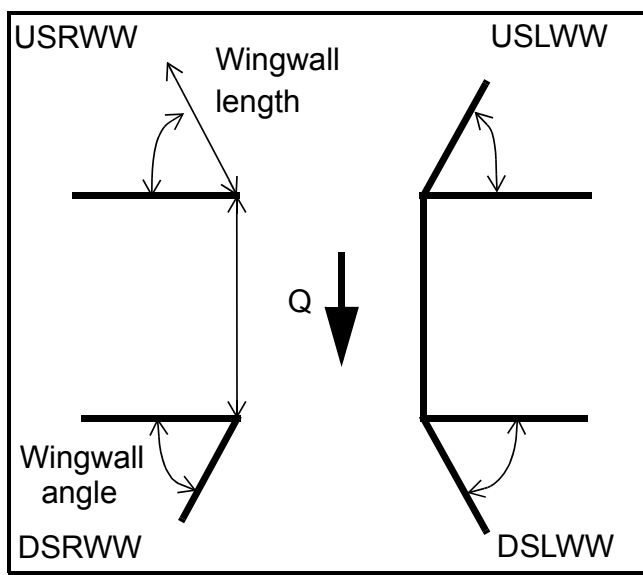

82. Bank / Bridge Protection:

\begin{tabular}{|l|l|l|l|l|l|l|l|l|}
\hline Location & USLWW & USRWW & LABUT & RABUT & LB & RB & DSLWW & DSRWW \\
\hline Type & $\mathbf{0 . 1}$ & $\mathbf{0}$ & & - & $\mathbf{1}$ & $\mathbf{1}$ & - & - \\
\hline Condition & $\mathbf{Y}$ & - & $\mathbf{1}$ & - & $\mathbf{2}$ & $\mathbf{2}$ & - & - \\
\hline Extent & $\mathbf{1}$ & - & $\mathbf{0}$ & $\mathbf{2}$ & $\mathbf{4}$ & $\mathbf{0}$ & $\mathbf{0}$ & - \\
\hline
\end{tabular}

Bank / Bridge protection types: 0- absent; 1- < 12 inches; 2- < 36 inches; 3- < 48 inches; 4- < 60 inches; 
83. Wingwall and protection comments (eg. undermined penetration, unusual scour processes, etc.):

-
-
-
-
-
2
1
3
2
1
1

Piers:

84. Are there piers? \#80 (Y or if $N$ type ctrl-n pr)

\begin{tabular}{|l|l|l|l|l|l|l|l|}
\hline \multirow{2}{*}{$\begin{array}{l}85 . \\
\text { Pier no. }\end{array}$} & \multicolumn{3}{|c|}{ width (w) feet } & \multicolumn{3}{c|}{ elevation (e) feet } \\
\cline { 2 - 8 } & w1 & w2 & w3 & e@w1 & e@w2 & e@w3 \\
\hline Pier 1 & & & & $\mathbf{3 0 . 0}$ & $\mathbf{2 4 . 0}$ & $\mathbf{9 0 . 0}$ \\
\hline Pier 2 & & & & $\mathbf{1 5 . 0}$ & $\mathbf{9 0 . 0}$ & $\mathbf{1 4 . 5}$ \\
\hline Pier 3 & & & - & $\mathbf{3 0 . 0}$ & $\mathbf{2 4 . 0}$ & - \\
\hline Pier 4 & - & - & - & - & - & - \\
Nyyyy
\end{tabular}

\begin{tabular}{|l|l|l|l|l|}
\hline Level 1 Pier Descr. & \multicolumn{1}{|c|}{1} & \multicolumn{1}{|c|}{2} & \multicolumn{1}{|c|}{3} & \multicolumn{1}{|c|}{4} \\
\hline 86. Location (BF) & :Scour & r ends & the & act as \\
\hline 87. Type & is & at & USR & a \\
\hline 88. Material & abou & RAB & WW & wall \\
\hline 89. Shape & t 0.1 & UT & area, & in \\
\hline 90. Inclined? & feet & junc- & place & front \\
\hline 91. Attack $\angle$ (BF) & belo & tion & d & of \\
\hline 92. Pushed & W & with & boul- & and \\
\hline 93. Length (feet) & - & - & - & - \\
\hline 94. \# of piles & top & DSR & ders & at \\
\hline 95. Cross-members & of & WW. & in & the \\
\hline 96. Scour Condition & foot- & & impa & end \\
\hline 97. Scour depth & ing. & $\# \mathbf{~}$ & ct & of \\
\hline 98. Exposure depth & Scou & In & zone & the \\
\hline
\end{tabular}

LFP, LTB, LB, MCL, MCM, MCR, RB, RTB, RFP

1- Solid pier, 2- column, 3- bent

1-Wood; 2- concrete; 3- metal; 4- stone

1- Round; 2- Square; 3- Pointed

Y-yes; $N-$ no

$L B$ or $R B$

0- none; 1- laterals; 2- diagonals; 3- both

0- not evident; 1- evident (comment);

2- footing exposed; 3- piling exposed;

4- undermined footing; 5- settled; 6 - failed 
99. Pier comments (eg. undermined penetration, protection and protection extent, unusual scour processes, etc.): wingwall.

$\mathbf{N}$

$-$

100.

\section{E. Downstream Channel Assessment}

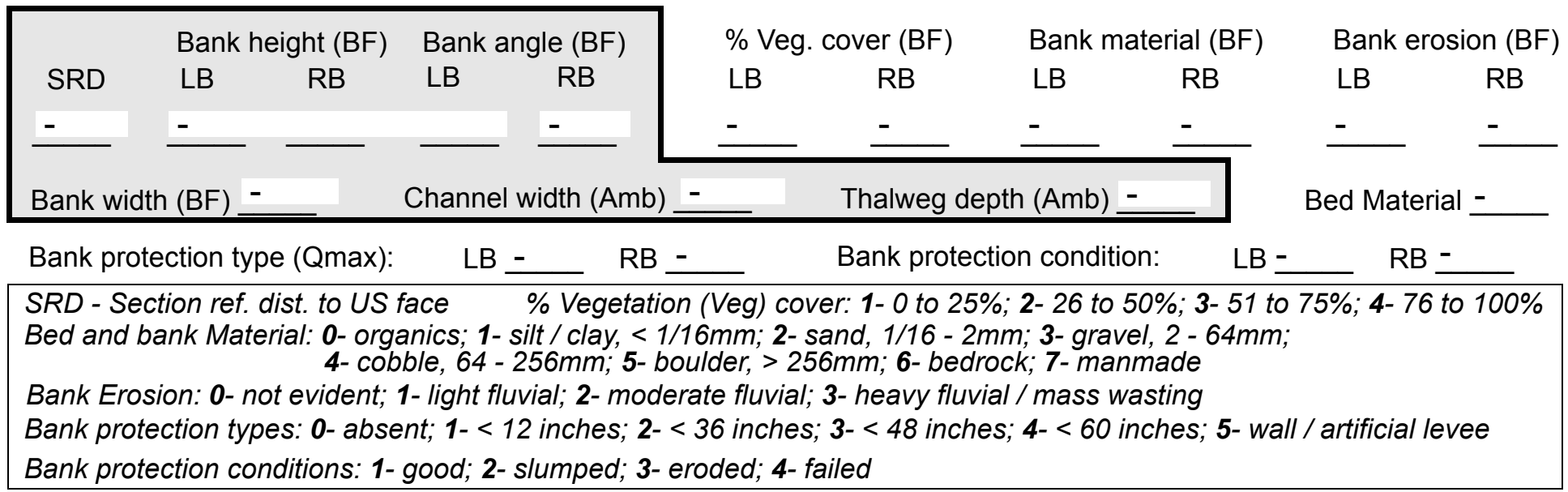

Comments (eg. bank material variation, minor inflows, protection extent, etc.):

$-$

$-$

$-$

$-$

$-$

$-$

$-$

$-$

$-$

$-$

$-$

$-$

$-$

$-$

$-$

\section{Is a drop structure present? __ ( $Y$ or $N$, if $N$ type ctrl-n $d s) \quad$ 102. Distance: ___ feet}

103. Drop: __ feet 104. Structure material: __ (1- steel sheet pile; 2- wood pile; 3- concrete; 4- other)

105. Drop structure comments (eg. downstream scour depth):

$-$

$-$

$-$

$-$

$-$

- 
106. Point/Side bar present? (Y or $N$. if $N$ type ctrl-n pb)Mid-bar distance:

Mid-bar width: -

Point bar extent: feet -

(US, UB, DS) to feet (US, UB, DS) positioned $\%$ LB to $\% \mathrm{RB}$

Material:

Point or side bar comments (Circle Point or Side; note additional bars, material variation, status, etc.):

$-$

-There are no piers.

Is a cut-bank present? (Y or if $N$ type ctrl-n cb) Where? (LB or $R B)$

Mid-bank distance:

Cut bank extent: feet (US, UB, DS) to feet (US, UB, DS)

Bank damage: (1- eroded and/or creep; 2- slip failure; 3- block failure)

Cut bank comments (eg. additional cut banks, protection condition, etc.): 4

4

453

543

Is channel scour present? 1 (Y or if $N$ type ctrl-n cs) Mid-scour distance: $\mathbf{2}$ Scour dimensions: Length $\underline{\mathbf{3 4 5}}$ Width $\mathbf{0}$ Depth: $\mathbf{0} \quad$ Positioned - _ \% $\%$ LB to _- $\%$ RB

Scour comments (eg. additional scour areas, local scouring process, etc.):

The right bank has moderate erosion from 35 feet downstream to 85 feet downstream. The most severely eroded section is $\mathbf{4 0}$ feet downstream. This part of the right bank is on the inside of a 90 degree bend in the channel.

There is also a major bend in channel 235 feet downstream.

Are there major confluences? ( $Y$ or if $N$ type ctrl-n $m c)$

How many?

Confluence 1: Distance Enters on (LB or $R B)$

Type (1-perennial; 2- ephemeral)

Confluence 2: Distance

Enters on (LB or $R B)$

Type (1- perennial; 2- ephemeral)

Confluence comments (eg. confluence name):

\section{F. Geomorphic Channel Assessment}

107. Stage of reach evolution

1- Constructed

2- Stable

3- Aggraded

4- Degraded

5- Laterally unstable

6- Vertically and laterally unstable 
108. Evolution comments (Channel evolution not considering bridge effects; See HEC-20, Figure 1 for geomorphic descriptors):

Y

4

The drop structure is formed by two logs placed in a $\mathrm{V}$ configuration. The Forest Service has placed logs in a similar $V$ configuration throughout the stream in order to create a stable environment for fish.

$\mathbf{Y}$

65

8

50

DS 


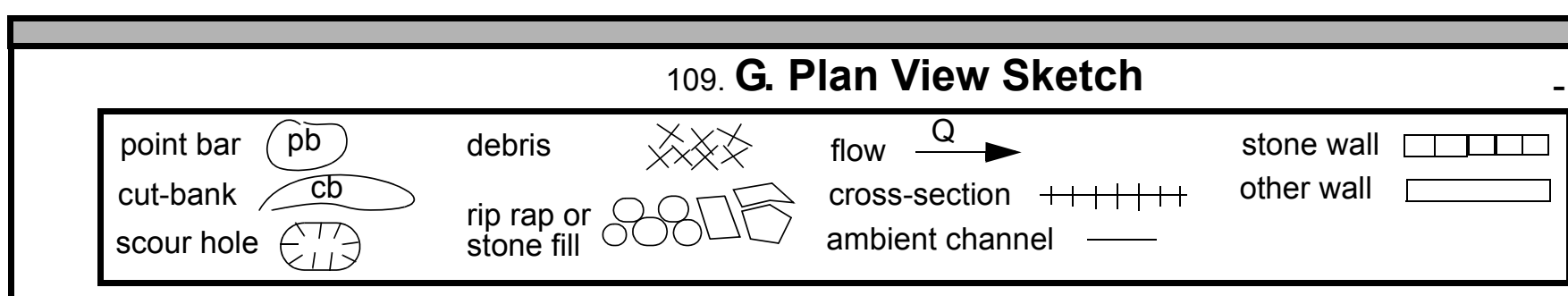


APPENDIX F:

SCOUR COMPUTATIONS 
SCOUR COMPUTATIONS

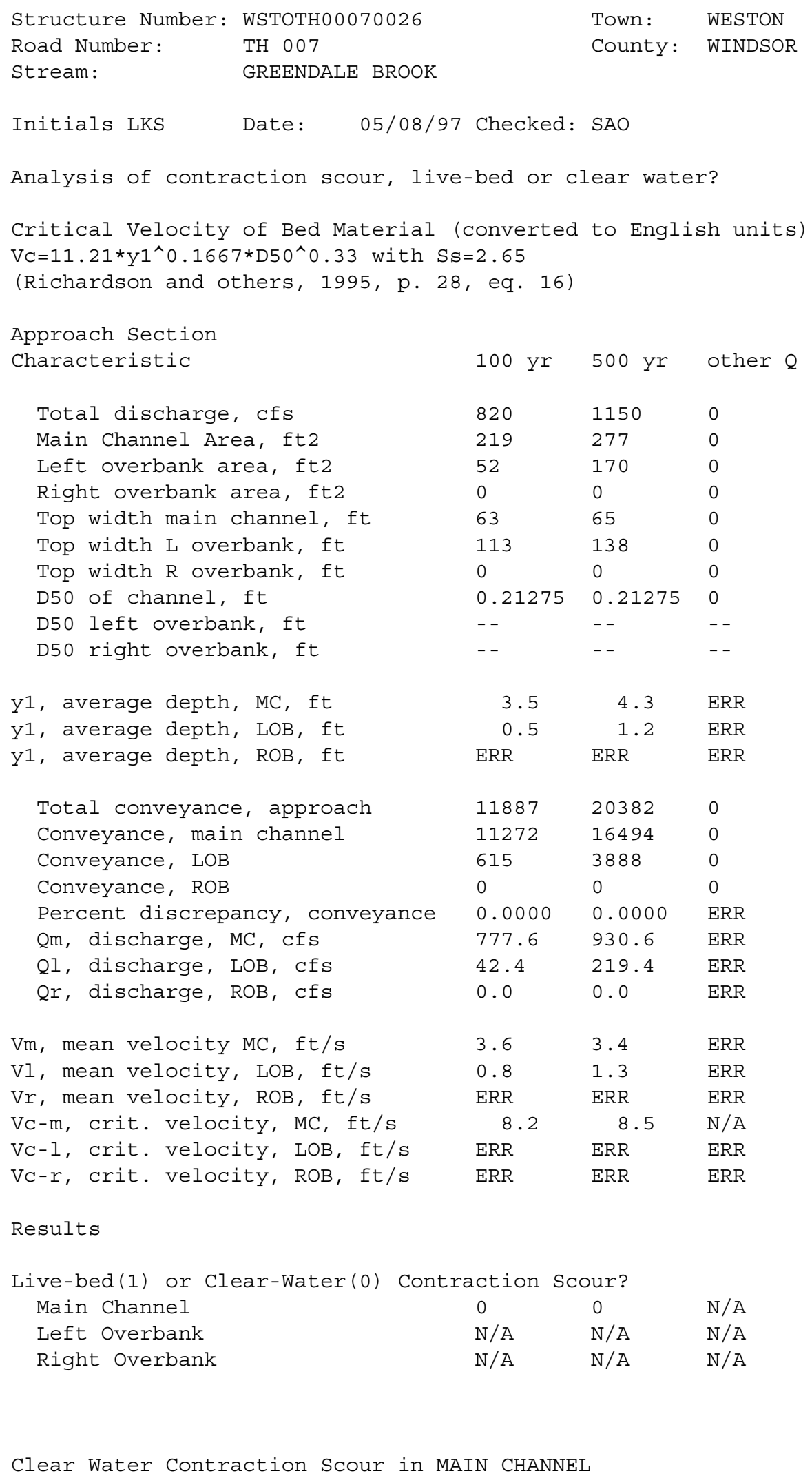




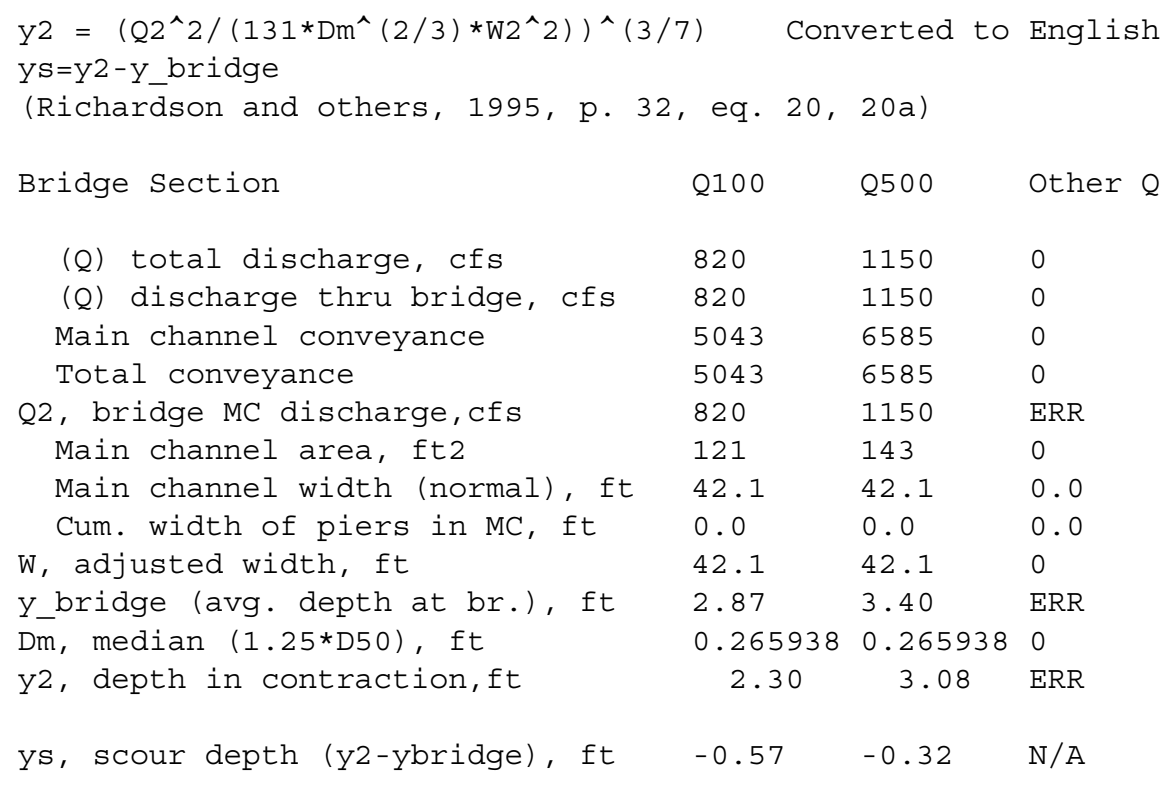

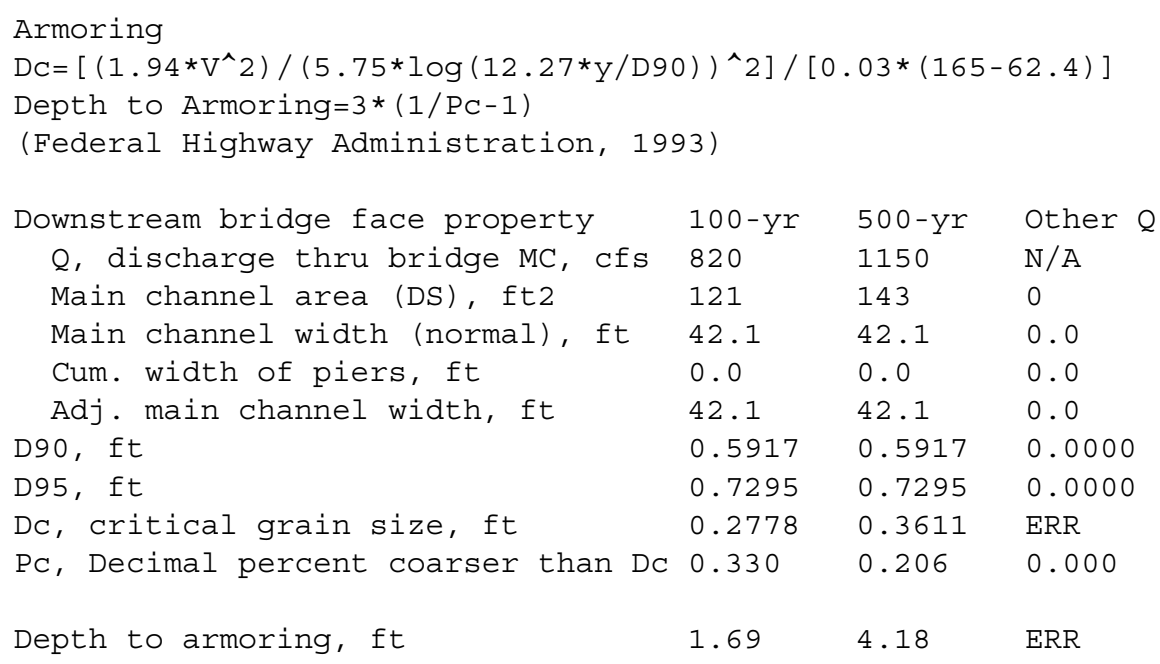

Abutment scour

Froehlich's Abutment Scour

$\mathrm{Ys} / \mathrm{Y} 1=2.27 * \mathrm{~K} 1 * \mathrm{~K} 2 *\left(\mathrm{a}^{\prime} / \mathrm{Y} 1\right)^{\wedge} 0.43 * \mathrm{Fr} 1 \wedge 0.61+1$

(Richardson and others, 1995, p. 48, eq. 28)

\begin{tabular}{|c|c|c|c|c|c|c|}
\hline \multirow[b]{2}{*}{ Characteristic } & \multicolumn{2}{|c|}{ Left Abutment } & \multicolumn{4}{|c|}{ Right Abutment } \\
\hline & $100 \mathrm{yr}$ & 00 yr Q & ther Q & 100 yr Q & $0 \mathrm{yr} 0$ & ther $Q$ \\
\hline (Qt), total discharge, cfs & 820 & 1150 & 0 & 820 & 1150 & 0 \\
\hline a', abut.length blocking flow, ft & 112.8 & 138.1 & 0 & 21.2 & 22.5 & 0 \\
\hline Ae, area of blocked flow ft 2 & 54.03 & 170.97 & 0 & 53.69 & 73.89 & 0 \\
\hline Qe, discharge blocked abut.,cfs & 49.6 & 222.65 & 0 & 149.65 & 200.1 & 0 \\
\hline (If using Qtotal_overbank to ok & & ve Qe $\mathrm{k}$ & & enter Ve & Id Fr $n$ & \\
\hline Ve, $(\mathrm{Qe} / \mathrm{Ae}), \mathrm{ft} / \mathrm{s}$ & 0.92 & 1.30 & $\mathrm{ERR}$ & 2.79 & 2.71 & $\mathrm{ERR}$ \\
\hline ya, depth of $f / p$ flow, ft & 0.48 & 1.24 & ERR & 2.53 & 3.28 & $\mathrm{ERR}$ \\
\hline
\end{tabular}




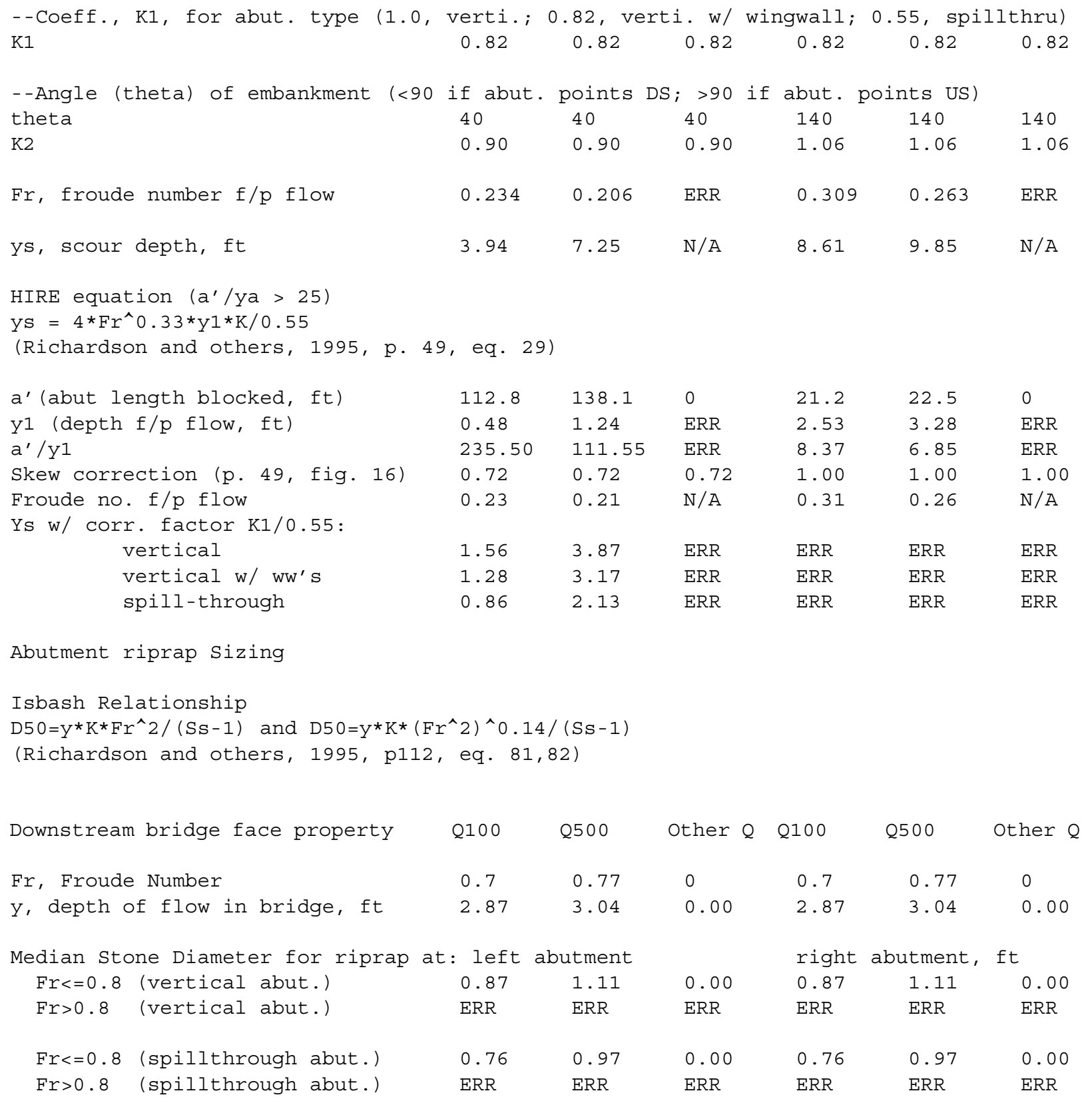


